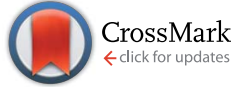

Cite this: RSC Adv., 2015, 5, 27986

Received 28th October 2014 Accepted 12th March 2015

DOI: $10.1039 / \mathrm{c} 4 \mathrm{ra13315c}$

www.rsc.org/advances

\section{Free radicals, natural antioxidants, and their reaction mechanisms}

\author{
Satish Balasaheb Nimse*a and Dilipkumar Pal ${ }^{\mathrm{b}}$
}

The normal biochemical reactions in our body, increased exposure to the environment, and higher levels of dietary xenobiotic's result in the generation of reactive oxygen species (ROS) and reactive nitrogen species (RNS). The ROS and RNS create oxidative stress in different pathophysiological conditions. The reported chemical evidence suggests that dietary antioxidants help in disease prevention. The antioxidant compounds react in one-electron reactions with free radicals in vivo/in vitro and prevent oxidative damage. Therefore, it is very important to understand the reaction mechanism of antioxidants with the free radicals. This review elaborates the mechanism of action of the natural antioxidant compounds and assays for the evaluation of their antioxidant activities. The reaction mechanisms of the antioxidant assays are briefly discussed (165 references). Practical applications: understanding the reaction mechanisms can help in evaluating the antioxidant activity of various antioxidant compounds as well as in the development of novel antioxidants.

\section{Introduction and background}

Antioxidants are molecules that inhibit or quench free radical reactions and delay or inhibit cellular damage. ${ }^{1}$ Though the antioxidant defenses are different from species to species, the presence of the antioxidant defense is universal. Antioxidants exists both in enzymatic and non-enzymatic forms in the intracellular and extracellular environment.

Normal biochemical reactions, increased exposure to the environment, and higher levels of dietary xenobiotics result in the generation of reactive oxygen species (ROS) and reactive nitrogen species (RNS). ${ }^{2}$ ROS and RNS are responsible for the oxidative stress in different pathophysiological conditions. ${ }^{3}$ Cellular constituents of our body are altered in oxidative stress conditions, resulting in various disease states. The oxidative stress can be effectively neutralized by enhancing cellular defenses in the form of antioxidants., ${ }^{4,5}$ Certain compounds act as in vivo antioxidants by raising the levels of endogenous antioxidant defenses. Expression of genes encoding the enzymes such as superoxide dismutase (SOD), catalase (CAT), glutathione peroxidase (GSHPx) increases the level of endogenous antioxidants. ${ }^{6}$

Antioxidants can be categorized in multiple ways. Based on their activity, they can be categorized as enzymatic and nonenzymatic antioxidants. Enzymatic antioxidants work by breaking down and removing free radicals. The antioxidant

anstitute for Applied Chemistry, Department of Chemistry, Hallym University, Chuncheon, 200-702, Korea. E-mail: satish_nimse@hallym.ac.kr; Fax: +82-33-2563421; Tel: $+82-33-248-2076$

${ }^{b}$ Institute of Pharmaceutical Sciences, Guru Ghasidas Vishwavidyalaya (A Central University), Koni, Bilaspur, Chhattisgarh-495009, India enzymes convert dangerous oxidative products to hydrogen peroxide $\left(\mathrm{H}_{2} \mathrm{O}_{2}\right)$ and then to water, in a multi-step process in presence of cofactors such as copper, zinc, manganese, and iron. Non-enzymatic antioxidants work by interrupting free radical chain reactions. Few examples of the non-enzymatic antioxidants are vitamin $\mathrm{C}$, vitamin E, plant polyphenol, carotenoids, and glutathione. ${ }^{7}$

The other way of categorizing the antioxidants is based on their solubility in the water or lipids. The antioxidants can be categorized as water-soluble and lipid-soluble antioxidants. The water-soluble antioxidants (e.g. vitamin C) are present in the cellular fluids such as cytosol, or cytoplasmic matrix. The lipid-soluble antioxidants (e.g. vitamin E, carotenoids, and lipoic acid) are predominantly located in cell membranes.

The antioxidants can also be categorized according to their size, the small-molecule antioxidants and large-molecule antioxidants. The small-molecule antioxidants neutralize the ROS in a process called radical scavenging and carry them away. The main antioxidants in this category are vitamin $\mathrm{C}$, vitamin $\mathrm{E}$, carotenoids, and glutathione (GSH). The large-molecule antioxidants are enzymes (SOD, CAT, and GSHPx) and sacrificial proteins (albumin) that absorb ROS and prevent them from attacking other essential proteins.

To understand the mechanism of action of antioxidants, it is necessary to understand the generation of free radicals and their damaging reactions. This review elaborates the generation and damages that free radicals create, mechanism of action of the natural antioxidant compounds and assays for the evaluation of their antioxidant properties. The reaction mechanisms of the antioxidant assays are discussed. The scope of this article 
is limited to the natural antioxidants and the in vitro assays for evaluation of their antioxidant properties.

\section{Generation of free radicals}

The generation of ROS (Table 1) begins with rapid uptake of oxygen, activation of NADPH oxidase, and the production of the superoxide anion radical $\left(\mathrm{O}_{2}{ }^{--}\right.$, eqn (1)),

$$
2 \mathrm{O}_{2}+\mathrm{NADPH} \stackrel{\text { (oxidase) }}{\longrightarrow} 2 \mathrm{O}_{2} \cdot-\mathrm{NADP}^{+}+\mathrm{H}^{+}
$$

The $\mathrm{O}_{2}{ }^{\cdot-}$ is then rapidly converted to $\mathrm{H}_{2} \mathrm{O}_{2}$ (eqn (2)) by SOD

$$
2 \mathrm{O}_{2} \cdot-{ }^{--}+2 \mathrm{H}^{+} \stackrel{\text { (SOD) }}{\longrightarrow} \mathrm{H}_{2} \mathrm{O}_{2}+\mathrm{O}_{2}
$$

These ROS can act by either of the two oxygen dependent mechanisms resulting in the destruction of the microorganism or other foreign matter. The reactive species can also be generated by the myeloperoxidase-halide- $\mathrm{H}_{2} \mathrm{O}_{2}$ system. The enzyme myeloperoxidase (MPO) is present in the neutrophil cytoplasmic granules. In presence of the chloride ion, which is ubiquitous, $\mathrm{H}_{2} \mathrm{O}_{2}$ is converted to hypochlorous ( $\mathrm{HOCl}$, eqn (3)), a potent oxidant and antimicrobial agent. ${ }^{8}$

$$
\mathrm{Cl}^{-}+\mathrm{H}_{2} \mathrm{O}_{2}+\mathrm{H}^{+} \stackrel{(\text { MPO) }}{\longrightarrow} \mathrm{HOCl}+\mathrm{H}_{2} \mathrm{O}
$$

ROS are also generated from $\mathrm{O}_{2}{ }^{--}$and $\mathrm{H}_{2} \mathrm{O}_{2}$ via 'respiratory burst' by Fenton (eqn (4)) and/or Haber-Weiss (eqn (5)) reactions. ${ }^{9}$

$$
\begin{gathered}
\mathrm{H}_{2} \mathrm{O}_{2}+\mathrm{Fe}^{2+} \rightarrow \cdot \mathrm{OH}+\mathrm{OH}^{-}+\mathrm{Fe}^{3+} \\
\mathrm{O}_{2}{ }^{\cdot-}+\mathrm{H}_{2} \mathrm{O}_{2} \rightarrow{ }^{\cdot} \mathrm{OH}+\mathrm{OH}^{-}+\mathrm{O}_{2}
\end{gathered}
$$

The enzyme nitric oxide synthase produce reactive nitrogen species (RNS), such as nitric oxide (NO') from arginine (eqn (6)).

$$
\mathrm{L}-\mathrm{Arg}+\mathrm{O}_{2}+\mathrm{NADPH} \rightarrow \mathrm{NO}^{*}+\text { citrulline }
$$

An inducible nitric oxide synthase (iNOS) is capable of continuously producing large amount of $\mathrm{NO}^{\circ}$, which act as a $\mathrm{O}_{2}{ }^{\cdot-}$ quencher. The NO $\mathrm{N}^{\cdot}$ and $\mathrm{O}_{2}{ }^{\cdot-}$ react together to produce peroxynitrite $\left(\mathrm{ONOO}^{-}\right.$, eqn (7)), a very strong oxidant, hence, each can modulate the effects of other. Although neither NO' nor $\mathrm{O}_{2}{ }^{--}$is a strong oxidant, peroxynitrite is a potent and

Table 1 List of the ROS ${ }^{165}$

\begin{tabular}{ll}
\hline Symbol & Name \\
\hline${ }^{1} \mathrm{O}_{2}$ & Singlet oxygen \\
$\mathrm{O}_{2}{ }^{--}$ & Superoxide anion radical \\
${ }^{\circ} \mathrm{OH}$ & Hydroxyl radical \\
$\mathrm{RO} \cdot$ & Alkoxyl radical \\
$\mathrm{ROO}^{\cdot}$ & Peroxyl radical \\
$\mathrm{H}_{2} \mathrm{O}_{2}$ & Hydrogen peroxide \\
LOOH & Lipid hydroperoxide
\end{tabular}

versatile oxidant that can attack a wide range of biological targets. ${ }^{10}$

$$
\mathrm{NO}+\mathrm{O}_{2}^{\cdot-} \rightarrow \mathrm{ONOO}^{-}
$$

Peroxynitrite reacts with the aromatic amino acid residues in the enzyme resulting in the nitration of the aromatic amino acids. Such a change in the aminoacid residue can result in the enzyme inactivation. However, nitric oxide is an important cytotoxic effector molecule in the defense against tumor cells, various protozoa, fungi, helminthes, and mycobacteria. ${ }^{112}$ The other sources of free radical reactions are cyclooxygenation, lipooxygenation, lipid peroxidation, metabolism of xenobiotics, and ultraviolet radiations. ${ }^{13}$

\section{Damaging reactions of free radicals}

ROS (Table 1) induced oxidative stress is associated with the chronic diseases such as cancer, coronary heart disease (CHD), and osteoporosis. ${ }^{14}$ Free radicals attack all major classes of biomolecules, mainly the polyunsaturated fatty acids (PUFA) of cell membranes. The oxidative damage of PUFA, known as lipid peroxidation is particularly destructive, because it proceeds as a self-perpetuating chain reaction..$^{15,16}$

The general process of lipid peroxidation can be envisaged as depicted bellow (eqn (8)-(11)), where LH is the target PUFA and $\mathrm{R}^{*}$ is the initializing, oxidizing radical. Oxidation of the PUFA generates a fatty acid radical $\left(\mathrm{L}^{*}\right)$ (eqn (8)), which rapidly adds oxygen to form a fatty acid peroxyl radical (LOO', eqn (9)). The peroxyl radicals are the carriers of the chain reactions. The peroxyl radicals can further oxidize PUFA molecules and initiate new chain reactions, producing lipid hydroperoxides (LOOH) (eqn (10) and (11)) that can break down to yet more radical species. $^{17}$

$$
\begin{aligned}
& \mathrm{LH}+\mathrm{R}^{\cdot} \rightarrow \mathrm{L}^{\cdot}+\mathrm{RH} \\
& \mathrm{L}^{\cdot}+\mathrm{O}_{2} \rightarrow \mathrm{LOO}^{*} \\
& \mathrm{LOO}^{\circ}+\mathrm{LH} \rightarrow \mathrm{LOOH}+\mathrm{L}^{\circ} \\
& \mathrm{LOOH} \rightarrow \mathrm{LO}^{`}+\mathrm{LOO}^{*}+\text { aldehydes }
\end{aligned}
$$

Lipid hydroperoxides always break down to aldehydes. Many of these aldehydes are biologically active compounds, which can diffuse from the original site of attack and spread the attack to the other parts of the cell. ${ }^{18,19}$ Lipid peroxidation has been widely associated with the tissue injuries and diseases. ${ }^{20}$

Oxygen metabolism generates ${ }^{\circ} \mathrm{OH}, \mathrm{O}_{2}{ }^{--}$, and the nonradical $\mathrm{H}_{2} \mathrm{O}_{2}$. The ${ }^{\circ} \mathrm{OH}$ is highly reactive and reacts with biological molecules such as DNAs, proteins, and lipids, which results in the chemical modifications of these molecules. There are several research reports on the oxidative damage of DNA due to the ${ }^{\circ} \mathrm{OH} .^{21-23}$

The $\mathrm{OH}$ reacts with the basepairs of DNA, resulting in the oxidative damage of the heterocyclic moiety and the sugar moiety in the oligonucleotides by a variety of mechanisms. This type of oxidative damage to DNA is highly correlated to the 
physiological conditions such as mutagenesis, carcinogenesis, and aging. ${ }^{24,25}$ The addition reactions yield $\mathrm{OH}$-adduct radicals of DNA bases (Scheme 1), whereas the allyl radical of thymine and carbon-centered sugar radicals (Scheme 2) are formed from the abstraction reactions.

As shown in the Scheme 1 , the ${ }^{\circ} \mathrm{OH}$ reacts with the guanine of the DNA to produce the C-8-hydroxy-adduct radical of guanine, which is converted to the 2,6-diamino-4-hydroxy-5formamidopyrimidine upon reduction and ring opening reactions. However, the C-8-hydroxy-adduct radical of guanine is converted to the 8-hydroxyguanine upon oxidation reaction. The ${ }^{\circ} \mathrm{OH}$ radical reacts with the heterocyclic moiety of the thymine and cytosine at C5- and C6-positions, resulting in the C5-OH and $\mathrm{C6}-\mathrm{OH}$ adduct radicals, respectively. The oxidation reaction of these adduct radicals with water (followed by deprotonation) results in the formation of the cytosine glycol and thymine glycol, respectively. ${ }^{26}$ Overall, the reactions of the 'OH with the DNA bases result in the impaired dsDNA.

As shown in the Scheme 2 , the ${ }^{\circ} \mathrm{OH}$ reacts with the sugar moiety of DNA by abstracting an $\mathrm{H}$-atom from rom $\mathrm{C} 5$ carbon atom. One unique reaction of the $\mathrm{C}^{\prime}$-centered radical of the sugar moiety in DNA is the addition to the C8-position of the purine ring in the same nucleoside (e.g. guanine). This intramolecular cyclization results in the formation of the $8,5^{\prime}$-cyclopurine-2'-deoxynucleosides. The reactions of carbon-centered sugar radicals result in the DNA strand breaks and base-free sites by a variety of mechanisms.

Proteins are oxidatively damaged by the combined action of activated oxygen species and the trace metal ions such as $\mathrm{Fe}^{2+}$ and $\mathrm{Cu}^{2+}$. The amino acid's lysine, proline, histidine, and arginine have been found to be the most sensitive to oxidative

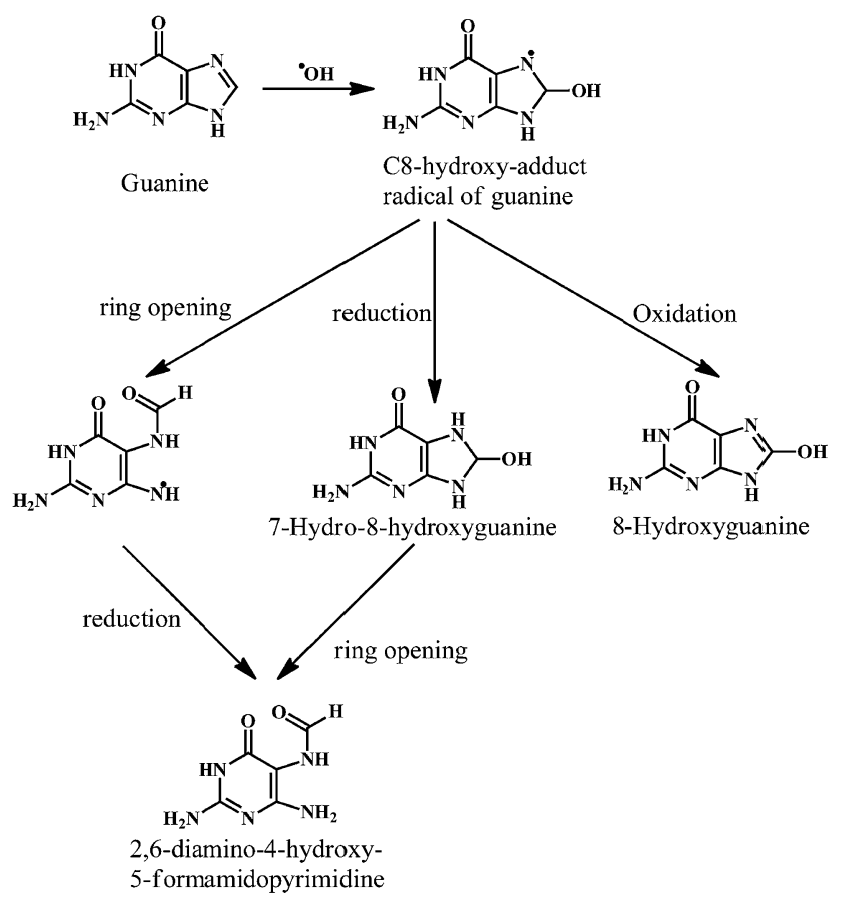

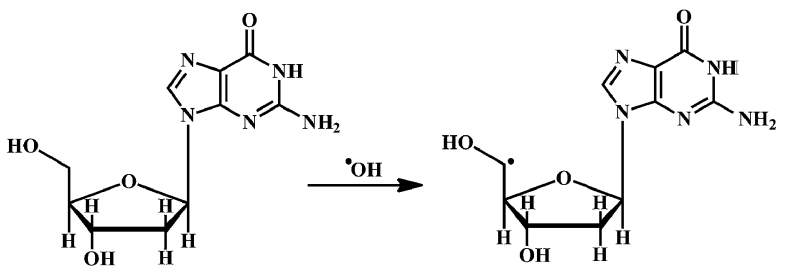

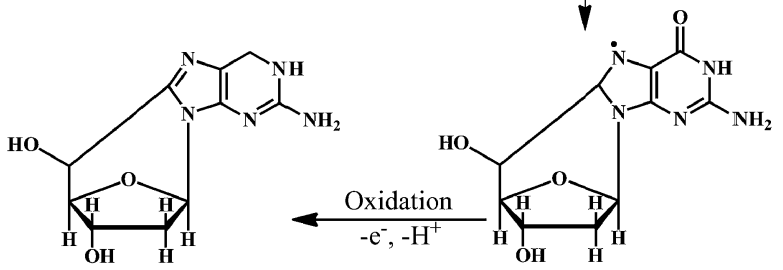

8,5'-cyclo-2'-deoxyguanosine

Scheme 2 Reaction of hydroxyl radical with the sugar moiety of DNA.

damage. Recent studies indicate that, a wide range of residue modifications can occur including formation of peroxides, ${ }^{27,28}$ and carbonyls. ${ }^{29}$ Generation of the carbonyl residue is a useful measure of oxidative damage to proteins. Thus, the oxidative damage to tissue results in the increased amount of oxidized protein. A detailed review by Cooke et al. provides important informations on the oxidative DNA damage, mechanisms, mutations, and related diseases. ${ }^{30}$

Low levels of antioxidants have been associated with the heart disease and cancer. ${ }^{31,32}$ Antioxidants provide protection against a number of disease processes such as aging, allergies, algesia, arthritis, asthma, atherosclerosis, autoimmune diseases, bronchopulmonary dyspepsia, cancer. The other disorders to which antioxidants provide protection are cataract, cerebral ischemia, diabetes mellitus, eczema, gastrointestinal inflammatory diseases, genetic disorders. ${ }^{33}$ Following section elaborates the mechanism of action of the radical scavenging activities of various natural antioxidant molecules.

\section{Modulation of free radicals by natural antioxidants}

Two types of antioxidants namely the enzymatic antioxidants and nonenzymatic antioxidants modulate the free radical reactions. Body protects itself from ROS by using enzymatic antioxidant mechanisms. ${ }^{34}$ The antioxidant enzymes reduce the levels of lipid hydroperoxide and $\mathrm{H}_{2} \mathrm{O}_{2}$, thus they are important in the prevention of lipid peroxidation and maintaining the structure and function of cell membranes. Examples of the enzymatic antioxidants (Fig. 1, Table 2) are CAT, GSHPx, SOD, and peroxiredoxin I-IV (I-IV).

$$
\begin{gathered}
2 \mathrm{H}_{2} \mathrm{O}_{2} \stackrel{\text { (catalase) }}{\longrightarrow} 2 \mathrm{H}_{2} \mathrm{O}+\mathrm{O}_{2} \\
\mathrm{ROOH}+2 \mathrm{GSH} \stackrel{(\text { GSHPx })}{\longrightarrow} \mathrm{ROH}+\mathrm{GSSG}
\end{gathered}
$$

Scheme 1 Reaction of hydroxyl radical with guanine. 

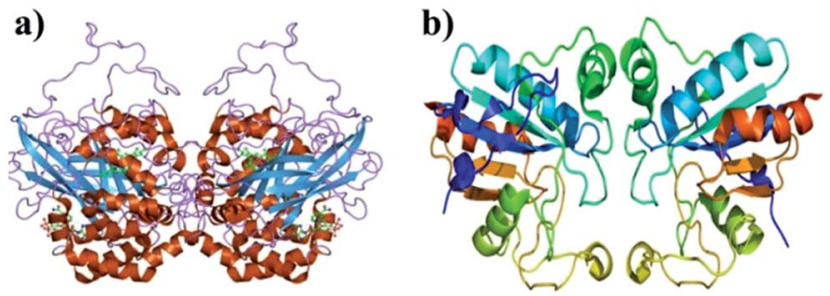

c)
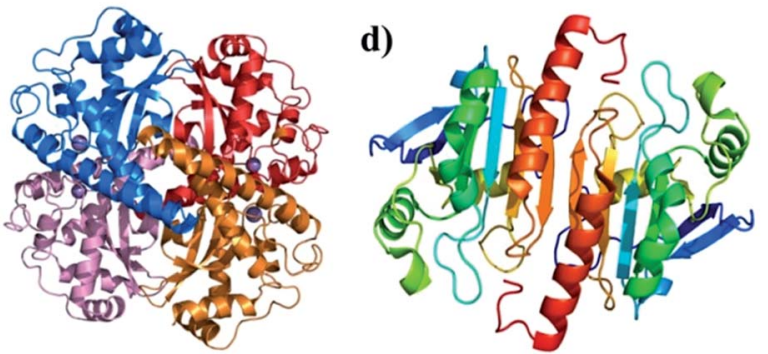

Fig. 1 (a) CAT, (b) GSHPx, (c) SOD, and Prx-I.

SOD's located in the cytosol and mitochondria, catalytically convert the $\mathrm{O}_{2}{ }^{\cdot-}$ into oxygen and $\mathrm{H}_{2} \mathrm{O}_{2}$ in presence of the metal ion cofactors such as copper $(\mathrm{Cu})$, zinc $(\mathrm{Zn})$, or manganese $(\mathrm{Mn}) .^{35}$ The enzyme CAT present in the peroxisome, converts $\mathrm{H}_{2} \mathrm{O}_{2}$ to water and oxygen (eqn (12)). ${ }^{36,37}$ GSHPx are found both in the cytoplasm and extracellularly in almost every human tissue. GSHPx convert the $\mathrm{H}_{2} \mathrm{O}_{2}$ into the water (Table 2). The enzyme GSHPx has strong activity towards both $\mathrm{H}_{2} \mathrm{O}_{2}$ and fatty acid hydroperoxides (eqn (13)). ${ }^{38,39}$ The enzyme peroxyredoxin catalyze the reduction of $\mathrm{H}_{2} \mathrm{O}_{2}$, organic hydroperoxides and the peroxynitrite $\left(\mathrm{ONOO}^{-}\right)$. The different expression profiles, subcellular locations, and substrates of the antioxidant enzymes reveal the complex nature of the ROS biology. Clearly, the antioxidant enzymes play a major role in the prevention of oxidative damage. As demonstrated in the Scheme 3, CAT, GSHPx, and SOD show synergistic effect in the scavenging of $\mathrm{O}_{2}{ }^{--}$.

The enzymatic antioxidants and their mechanism of antioxidant activity has been explained in details in several review articles. ${ }^{40-42}$ Therefore, this article focuses mainly on the nonenzymatic antioxidants of natural origin.

The nonenzymatic antioxidants are of two types, the natural antioxidants and the synthetic antioxidants. However, the scope of this article is limited to the natural antioxidants; hence the synthetic antioxidants will not be considered for the discussion.

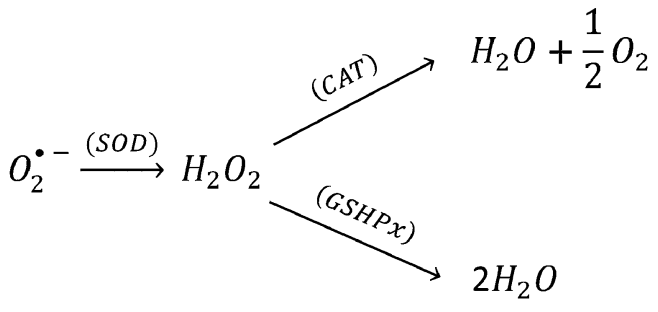

Scheme 3 Radical scavenging activity of SOD, CAT, and GSHPX.

\subsection{Vitamins}

Vitamin E $1,{ }^{43}$ vitamin C $2,{ }^{44}$ vitamin A 3.<smiles>CCCCCC1(C)CCc2c(C)c(O)c(C)c(C)c2O1</smiles><smiles>O=C1OC(C(O)CO)C(O)=C1O</smiles>

2<smiles>CC1=C(/C=C/C(C)=C/C=C/C(C)=C/CO)C(C)(C)CCC1</smiles>

3

Vitamin E ( $\alpha$-tocopherol) 1, is an efficient lipid soluble antioxidant that functions as a 'chain breaker' during lipid peroxidation in cell membranes and various lipid particles including low-density lipoprotein (LDL). It functions to intercept lipid peroxyl radicals ( $\mathrm{LOO}^{\circ}$ ) and to terminate the lipid peroxidation chain reactions (eqn (14)).

$$
\mathrm{LOO}^{*}+\alpha \text {-tocopherol-OH } \rightarrow \mathrm{LOOH}+\alpha \text {-tocopherol- } \mathrm{O}^{\bullet}
$$

The resultant tocopheroxyl radical is relatively stable and in normal circumstances, insufficiently reactive to initiate lipid peroxidation itself, which is an essential criterion of a good antioxidant. ${ }^{45-47}$ It should be noted that, vitamin $\mathrm{E}$ exerts

Table 2 Enzymatic antioxidants, their cellular locations and the reactions they carry out

\begin{tabular}{llll}
\hline Enzymatic antioxidant & Cellular location & Substrate & Reaction \\
\hline Mn/Cu/Zn SOD & Mitochondrial matrix (Mn SOD) cytosol (Cu/Zn SOD) & $\mathrm{O}_{2}{ }^{--}$ & $\mathrm{O}_{2}{ }^{\cdot-} \rightarrow \mathrm{H}_{2} \mathrm{O}_{2}$ \\
CAT & Peroxisomes cytosol & $\mathrm{H}_{2} \mathrm{O}_{2}$ & $2 \mathrm{H}_{2} \mathrm{O}_{2} \rightarrow \mathrm{O}_{2}+\mathrm{H}_{2} \mathrm{O}$ \\
GSHPx & Cytosol & $\mathrm{H}_{2} \mathrm{O}_{2}$ & $\mathrm{H}_{2} \mathrm{O}_{2}+\mathrm{GSH}_{\mathrm{GSS}} \rightarrow \mathrm{GSS}_{2} \mathrm{O}$ \\
Prx-I & Cytosol & $\mathrm{H}_{2} \mathrm{O}_{2}$ & $\mathrm{H}_{2} \mathrm{O}_{2}+\mathrm{TrxS}_{2} \rightarrow \mathrm{Trx}_{(\mathrm{SH})_{2}+\mathrm{H}_{2} \mathrm{O}}$
\end{tabular}


<smiles>O=C1OC(C(O)CO)C(O)=C1O</smiles>

Ascorbic acid

$\left(\mathrm{AscH}_{2}\right)$<smiles>C[C-]1CC1[C@H](O)C(O)CO</smiles>

Ascorbate

$\left(\mathrm{AscH}^{-}\right)$
Ascorbate radical

ÀscH

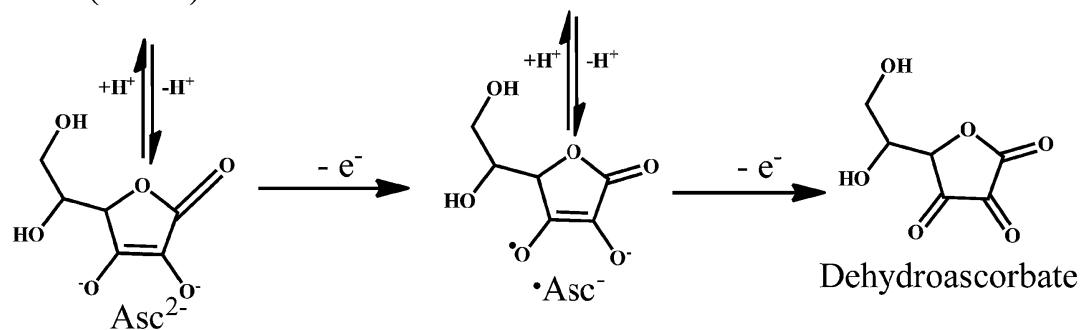

Scheme 4 Mechanism of radical scavenging activity of ascorbic acid 2

antioxidant effects by scavenging lipid peroxyl radicals in vivo as well as in vitro systems. However, vitamin $\mathrm{E}$ is not an efficient scavenger of ${ }^{\circ} \mathrm{OH}$ and alkoxyl radicals ( $\left.{ }^{\circ} \mathrm{OR}\right)$ in vivo. ${ }^{48}$

Vitamin $\mathrm{C}$ or ascorbic acid 2 , is a water-soluble free radical scavenger. Moreover, it regenerates vitamin $\mathrm{E}$ in cell membranes in combination with GSH or compounds capable of donating reducing equivalents. ${ }^{49-51}$ Vitamin $\mathrm{C}$, changes to the ascorbate radical (Scheme 4) by donating an electron to the lipid radical in order to terminate the lipid peroxidation chain reaction. The pairs of ascorbate radicals react rapidly to produce one molecule of ascorbate and one molecule of dehydroascorbate. The dehydroascorbate does not have any antioxidant capacity. Hence, dehydroascorbate is converted back into the ascorbate by the addition of two electrons. The last stage of the addition of two electrons to the dehydroascorbate has been proposed to be carried out by oxidoreductase.

Antioxidant potential of vitamin A 3 was first described by Monaghan and Schmitt, ${ }^{52}$ who reported that vitamin A can protect lipids against rancidity. Several reviews have appeared to outline the basic structural and metabolic characteristics of vitamin A and information about its potential as antioxidants in relation to the heart diseases. ${ }^{53,54}$ Vitamin $\mathrm{A}$ has a vital antioxidant contribution in protecting human LDL against copperstimulated oxidation (Scheme 5). ${ }^{55,56}$

\subsection{Bioflavonoids}

Flavonol 4 (e.g. quercetin 5, myricetin 6), flavone 7 (e.g. apigenin 8, luteoline 9), flavonolols 10 (e.g. taxifolin 11), flavan-3ols 12 (e.g. catechin 13, epigallocatechin 14), flavonone 15 (e.g. hesperetin 16, naringenin 17), anthocyanidin 18 (e.g. cynidin 19, delphidin 20), isoflavone 21 (e.g. genistein 22, daidzein 23). ${ }^{57,58}$<smiles>O=c1c(O)c(-c2ccccc2)oc2ccccc12</smiles>

4

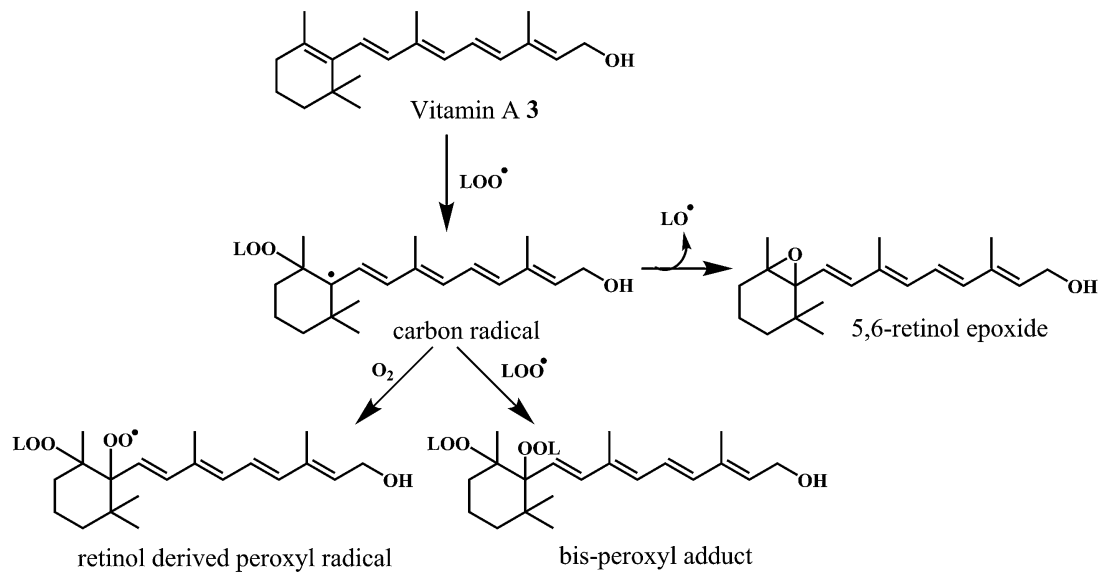

Scheme 5 Mechanism of radical scavenging activity of vitamin A 3. 
<smiles>O=c1c(O)c(-c2ccc(O)c(O)c2)oc2cc(O)cc(O)c12</smiles><smiles>O=C1c2c(O)cc(O)cc2OC(c2ccc(O)c(O)c2)C1O</smiles>

11<smiles>O=c1c(O)c(-c2cc(O)c(O)c(O)c2)oc2cc(O)cc(O)c12</smiles><smiles>OC1Cc2ccccc2OC1c1ccccc1</smiles>

12<smiles>O=c1cc(-c2ccccc2)oc2ccccc12</smiles>

7<smiles>Oc1cc(O)c2c(c1)OC(c1ccc(O)c(O)c1)C(O)C2</smiles>

13<smiles>O=c1cc(-c2ccc(O)cc2)oc2cc(O)cc(O)c12</smiles><smiles>Oc1cc(O)c2c(c1)OC(c1cc(O)c(O)c(O)c1)C(O)C2</smiles>

8<smiles>O=c1cc(-c2ccc(O)c(O)c2)oc2cc(O)cc(O)c12</smiles><smiles>O=C1CC(c2ccccc2)Oc2ccccc21</smiles>

9<smiles>O=C1c2c(O)cc(O)cc2OC(c2ccccc2)C1O</smiles> 
<smiles>O=C1CC(c2ccc(O)cc2)Oc2cc(O)cc(O)c21</smiles>

17<smiles>Oc1cc2ccccc2[o+]c1-c1ccccc1</smiles>

18<smiles>Oc1cc(O)c2cc(O)c(-c3ccc(O)c(O)c3)[o+]c2c1</smiles><smiles>Oc1cc(O)c2cc(O)c(-c3cc(O)c(O)c(O)c3)[o+]c2c1</smiles>
20<smiles>O=c1c(-c2ccccc2)coc2ccccc12</smiles>

21<smiles>O=c1c(-c2ccc(O)cc2)coc2cc(O)cc(O)c12</smiles><smiles>O=c1c(-c2ccc(O)cc2)coc2cc(O)ccc12</smiles>

23

Bioflavonoids are a group of natural benzo- $\gamma$-pyran derivatives (4-23) and are found to possess strong antioxidant activities. $^{59,60}$ Bioflavonoids widely distributed in fruits and vegetables, are reported to exert multiple biological effects including free radical-scavenging activity. It has been reported that the bioflavonoids have a protective effect on the DNA damage induced by the hydroxyl radicals. ${ }^{\mathbf{6 1}}$ One of the mechanisms that explains the protective effect of the flavonoids on the DNA is the involvement of the chelating metal ions, such as copper or iron. The flavonoids complexed with the copper or iron prevent the generation of the ROS. ${ }^{62-64}$

Quercetin 5 is a flavonol, known to protect DNA from oxidative damage resulting from the attack of ${ }^{\circ} \mathrm{OH}, \mathrm{H}_{2} \mathrm{O}_{2}$, and $\mathrm{O}_{2}{ }^{-}-$on the DNA oligonucleotides (Scheme 6). ${ }^{65}$ On the contrary, quercetin is also reported to be carcinogenic agent. ${ }^{\mathbf{6 6}, \mathbf{6 7}}$ According to the reports, quercetin has opposite effects on DNA damage induced by cupric ion depending on the concentration of cupric ion (Scheme 7). ${ }^{68,69}$ At the low concentration of cupric ions $(\leq 25 \mu \mathrm{M})$, quercetin exhibit a protective role. While, at higher concentration of cupric ion $(\geq 25 \mu \mathrm{M})$, quercetin enhances the damage to DNA by ROS. Therefore, it is very important to consider the concentration of the chelating metal ions, such as copper or iron while evaluating the protective or degenerative effects of quercetin and other bioflavonoids.

Anthocynidine, a class of flavonoids are potential antioxidants and their effectiveness in the inhibition of the lipid oxidation is related to their metal ion-chelating activity (Scheme 8) and free-radical scavenging activity (Scheme 9). Three structural groups are important determinants of the radical-scavenging activity of anthocynidines 18-20. ${ }^{70}$ First, the ortho-dihydroxy structure in the B-ring. Second, the 2,3 double bond in conjugation. Third, the 4-oxofunction in the C-ring. Flavonoids form complexes with the metal ions by using the 3- or 5-hydroxyl and 4-ketosubstituents or hydroxyl groups in ortho position in the B-ring. ${ }^{71}$

As shown in the Scheme 9, the anthocynidins (cynidin 19) can donate an electron (accompanied by a hydrogen nucleus) to a free radical from $-\mathrm{OH}$ groups attached to the phenolic rings. ${ }^{72-74}$ This electron stabilizes and inactivates the free radical. In this process, the polyphenolic reducing agent changes to an aroxyl radical, which is comparatively more stable due to resonance than the free radical that it has reduced. The overall result is the termination of damaging oxidative chain reactions. 


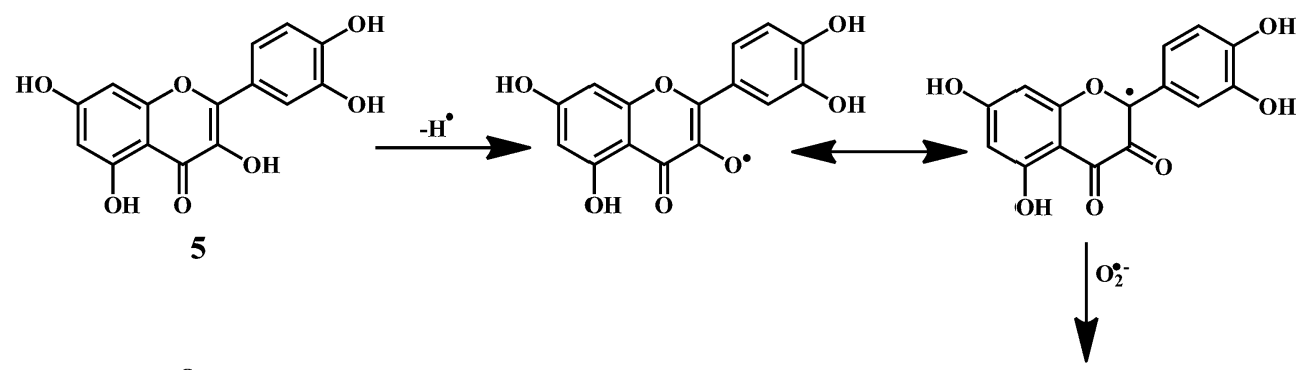

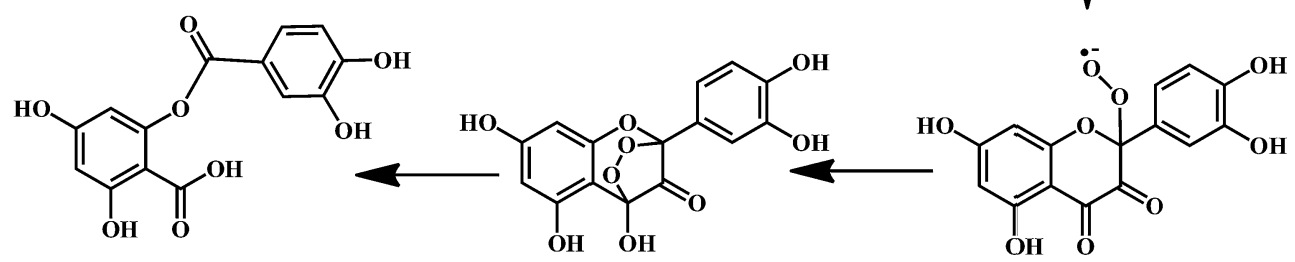

Scheme 6 Mechanism of superoxide anion radical scavenging activity of quercetin 5 .

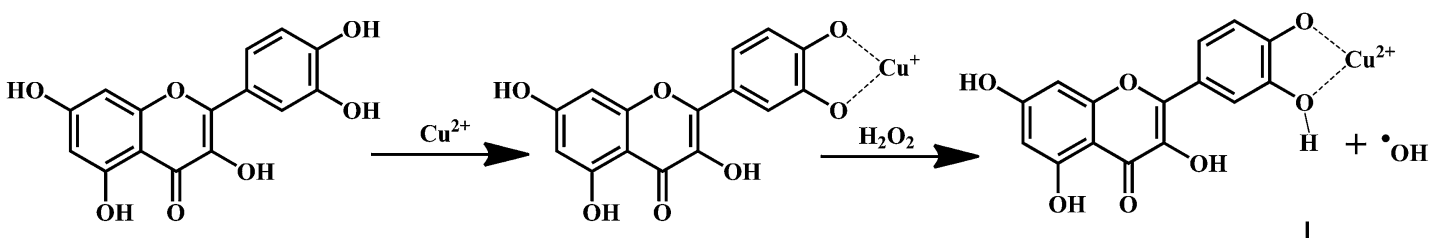

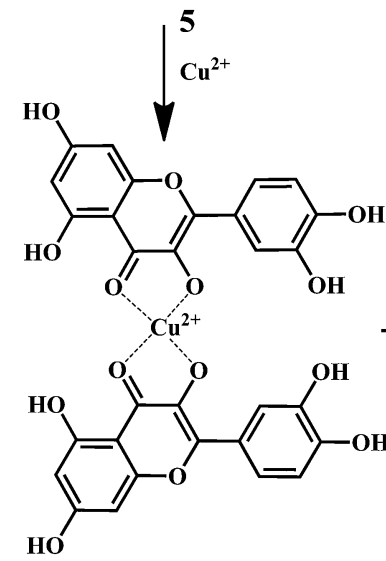

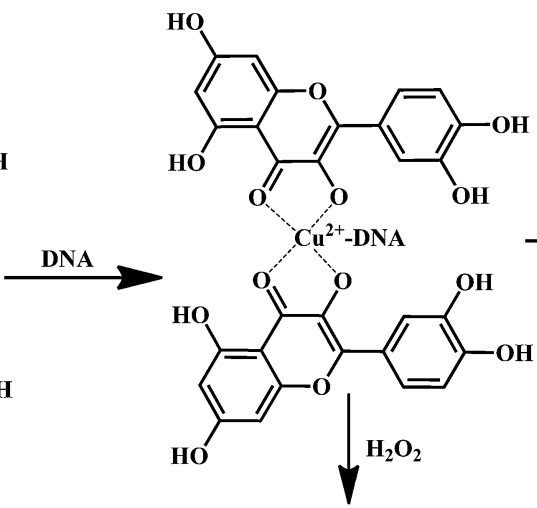

DNA

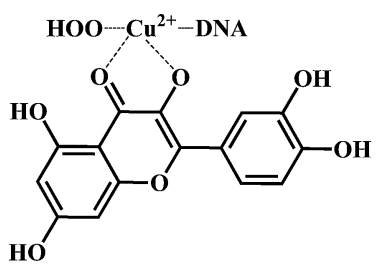

Hydrolysis

DNA damage

Scheme 7 Mechanism of DNA damage induced by quercetin copper complex.

\subsection{Carotenoids $\mathbf{s}^{75,76}$}

(i) Carotines: lycopene 26, $\beta$-carotene 27,

(ii) Xanthophyll: zeaxanthine 28, lutein 29.

Carotenoids are among the most common lipid soluble phytonutrients. Lycopene $\mathbf{2 4}$ and $\beta$-carotene 25 are the prominent carotenoids among other 600 different compounds. ${ }^{77}$ The biosynthetic pathway as shown in Scheme 10 demonstrates the synthesis of carotenoids 26-29 from phytoene 25, which is synthesized from two molecules of geranylgeranyl pyrophosphate
24. Carotenoids are well known to scavenge the peroxyl radicals more efficiently as compared to any other ROS. The peroxyl radicals generated in the process of lipid peroxidation can damage the lipids in the cell wall. Scavenging of peroxyl radicals can disrupt the reaction sequence and prevent the damage to cellular lipids. The long unsaturated alkyl chains in carotenoids make them highly lipophilic. Carotenoids are known to play an important role in the protection of cellular membranes and lipoproteins against the ROS due to their peroxyl radical 


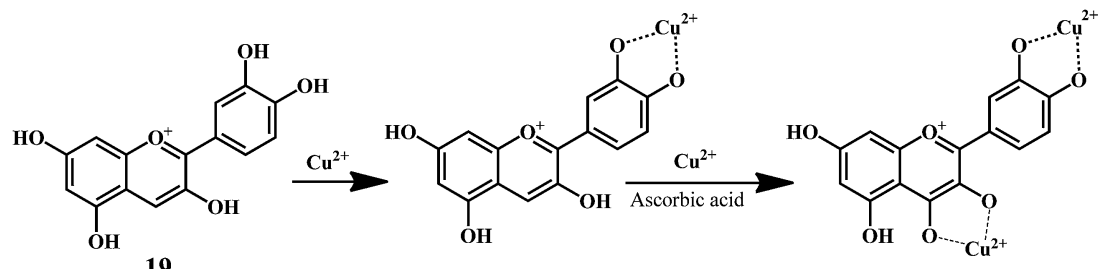

Scheme 8 Metal ion $\left(\mathrm{Cu}^{2+}\right)$ chelating activity of anthocynidine (cynidin 19).

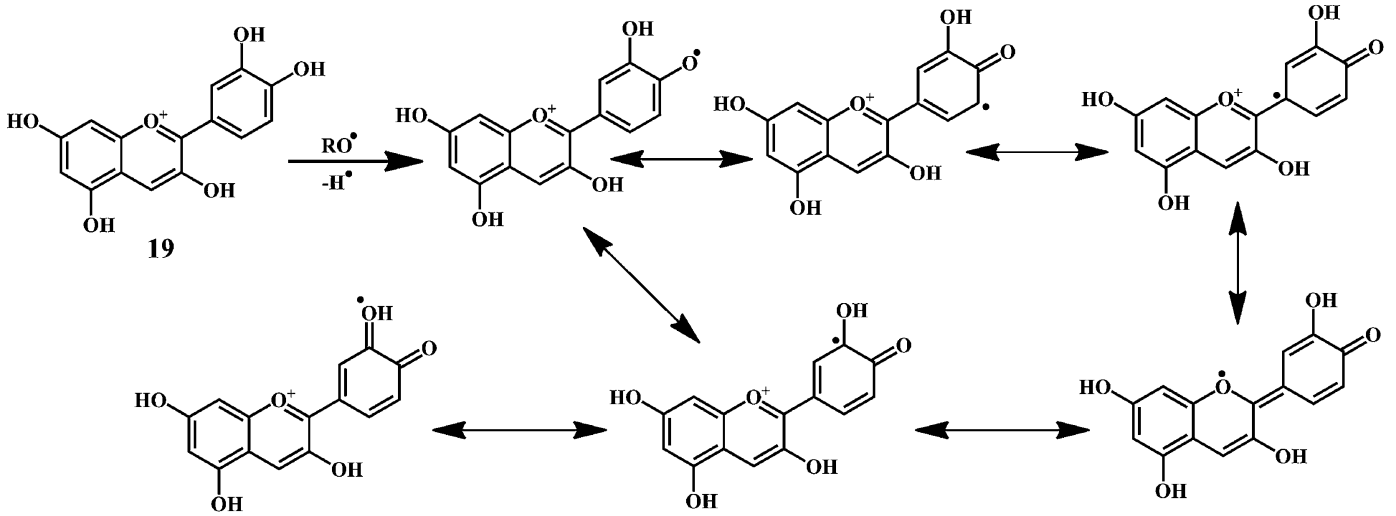

Scheme 9 Mechanism of radical scavenging activity of cynidin 19
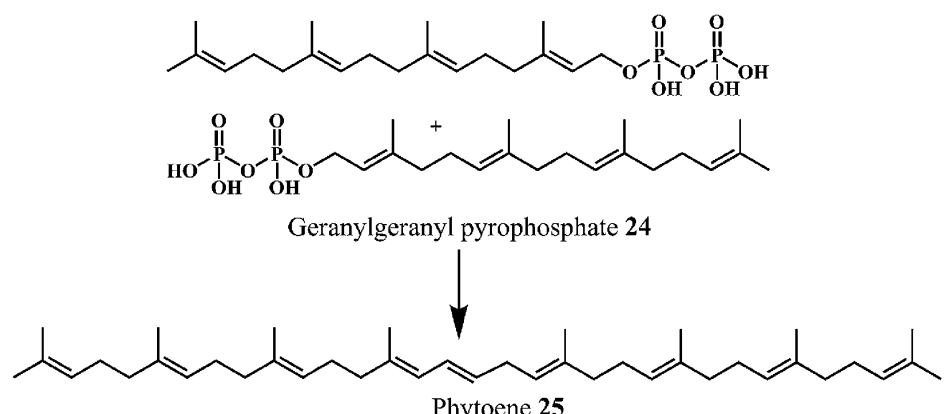<smiles>CC1=C(/C=C/C(C)=C/C=C/C(C)=C/CO)C(C)(C)CCC1</smiles>

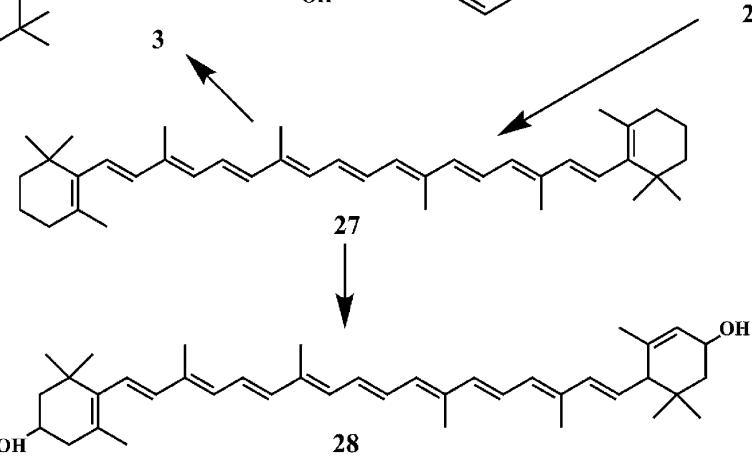

Phytoene 25

26

6<smiles>CC1=CCCC(C)(C)C1/C=C/C(C)=C/C=C/C(C)=C/C=C/C=C(C)/C=C/C=C(C)/C=C/C1=C(C)CCCC1(C)C</smiles><smiles>CC1=CC(O)CC(C)(C)C1/C=C/C(C)=C/C=C/C(C)=C/C=C/C=C(C)/C=C/C=C/C1=C(C)CC(O)CC1(C)C</smiles>

Scheme 10 Biosynthetic pathway for the synthesis of carotenoids 26-29. 
scavenging activity. ${ }^{78,79}$ Carotenoids deactivate the peroxyl radicals by reacting with them to form resonance stabilized carboncentered radical adducts.

Lycopene 24, is the most potent antioxidant naturally present in many fruits and vegetables. The high number of conjugated double bonds in lycopen endows it the singlet oxygen quenching ability. Lycopene demonstrate the strong singlet oxygen quenching ability as compared to the $\alpha$-tocopherol 1 or $\beta$-carotene $25 .^{\mathbf{8 0}} \beta$-Carotene 12 is a naturally occurring orange-colored carotenoid, abundantly found in the yelloworange fruits and in dark-green leafy vegetables. ${ }^{\mathbf{8 1 , 8 2}} \beta$-Carotene demonstrates potential antioxidant property due to its chemical structure and the interaction with biological membranes. ${ }^{83}$ It is well-known that, the $\beta$-carotene quenches singlet oxygen with higher efficiency as compared to the $\alpha$ tocopherol. ${ }^{84}$ In addition, it is also known that the $(Z)$-isomers of the $\beta$-carotene possess antioxidant activity in vitro. ${ }^{85,86}$ Furthermore, the $\beta$-carotene can be converted into the two molecules of vitamin $A$ by the $\beta$-carotene- $15,15^{\prime}$-dioxygenase catalyzed cleavage.

\subsection{Hydroxycinnamates}

The examples are ferulic acid 30, caffeic acid 31, sinapic acid 32, p-coumaric acid 33.<smiles>COc1cc(/C=C/C(=O)O)ccc1O</smiles>
30<smiles>O=C(O)/C=C/c1ccc(O)c(O)c1</smiles>

31<smiles>COc1cc(/C=C/C(=O)O)cc(OC)c1O</smiles><smiles>O=C(O)/C=C/c1ccc(O)cc1</smiles>

33
It is widely accepted that, the dietary antioxidants that protect LDL from oxidation can prevent the atherosclerosis and coronary heart disease. Hydroxycinnamic acids 30-33 and their conjugates prevent oxidative damage to the LDL. ${ }^{87}$ The in vitro studies involving human LDL as the oxidizing substrate showed that the hydroxycinnamic acids have higher antioxidant activity as compared to the corresponding hydroxybenzoic acids. ${ }^{88}$ The antioxidant activity of the derivatives of the hydroxycinnamates is clearly correlated with the hydroxylation and methylation patterns of the aromatic ring. The antioxidant efficiency of the free hydroxycinnamates on the human LDL oxidation in vitro, decreases in the order of caffeic acid $31>$ sinapic acid $32>$ ferulic acid $\mathbf{3 0}>$ p-coumaric acid $\mathbf{3 3}$.

The presence of the $o$-dihydroxy group in the phenolic ring (as in caffeic acid) enhances the antioxidant activity of hydroxycinnamic acids toward human LDL oxidation in vitro. ${ }^{89}$ The radical scavenging antioxidant mechanism of the hydroxycinnamic acids are similar to that of the flavanoids because of their ability to donate an hydroxyl hydrogen and resonance stabilization of the resulting antioxidant radicals. The $o$-dihydroxy substituents also allow the metal ion chelation similar to that of flavanoids.

\subsection{Other natural antioxidants}

Theaflavin 34, theaflavin-3-gallate 35, allicin 36, piperine 37, curcumin $38 . .^{\mathbf{9 0}, 91}$

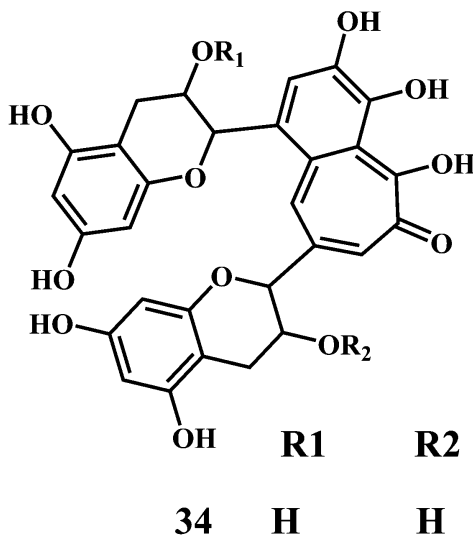

35 Gallate $\mathbf{H}$<smiles>C=CCSS(=O)CC=C</smiles>

36 
<smiles>COc1cc(C=CC(=O)CC(=O)/C=C/c2ccc(O)c(OC)c2)ccc1O</smiles>

38

Theaflavin 34 and theaflavin-3-gallate 35 possesses in vitro antioxidative properties against lipid peroxidation in the erythrocyte membranes and microsomes. They also suppress the mutagenic effects induced by $\mathrm{H}_{2} \mathrm{O}_{2} \cdot{ }^{92}$ Theaflavins inhibit the $\mathrm{H}_{2} \mathrm{O}_{2}$ induced cleavage and mutagenicity of the DNA single-strand..$^{93,94}$ In general, theaflavins scavenge the free radicals to produce antioxidative and antimutagenic effects. Apart from the aromatic hydroxyl groups of theaflavins, the gallic acid moiety is essential for their antioxidant activity. The theaflavin-3-gallate 35 is a stronger antioxidant than that of theaflavin 34. Moreover, the digallate derivatives of theaflavin demonstrate the increased antioxidant activity.

Allicin (diallyl thiosulfinate) $\mathbf{3 6}$ is the biologically active compound mainly found in the garlic extracts. Allicin is known to possess various biological activities including the antibacterial, antifungal, and inhibition of cancer promotion. ${ }^{95}$ Moreover, allicin is known to reduce serum cholesterol and triglyceride levels as well as atherosclerotic plaque formation and platelet aggregation. ${ }^{96}$ Until now, a variety of biological effects of allicin were attributed to antioxidant activity. ${ }^{97}$ However, recently it has been found that the active ingredients responsible for the antioxidant property of garlic is 2-propenesulfenic acid and not the allicin. ${ }^{98}$ Thiosulfinates undergoes Cope elimination to form sulfenic acids, thioaldehydes or thioketones. The $\mathrm{S}-\mathrm{S}$ bond in the thiosulfinate is much weaker than the $\mathrm{S}-\mathrm{C}$ bond in a sulfoxide. Hence, this process can occur at room temperature. Cope elimination is even more susceptible for the allyl (and benzyl) thiosulfinates, such as allicin 36, because of the weak $\beta \mathrm{C}-\mathrm{H}$ bond of the allyl moiety. Allicin is known to undergo Cope elimination at room temperature to give 2-propenesulfenic acid and thioacrolein as shown in the Scheme 11. ${ }^{99,100}$

The Scheme 12a demonstrate the mechanism of the radicalscavenging activity of the allicin. The radical-scavenging activity of allicin involves $\mathrm{H}$-atom transfer to a peroxyl radical from the methylene of the allyl group on the divalent sulfur. Scheme $12 \mathrm{~b}$ demonstrate an alternative mechanism, where the radicalscavenging activity of allicin can be accounted for 2-propenesulfenic acid, which is produced from allicin by Cope elimination. ${ }^{101}$ 2-Propenesulfenic acid is reported to be over 1000 times more reactive toward ${ }^{\circ} \mathrm{OOH}$ radicals than allicin $\left(2.60 \times 10^{7} \mathrm{vs}\right.$. $7.38 \times 10^{3} \mathrm{~L} \mathrm{~mol}^{-1} \mathrm{~s}^{-1}$, at $\left.298 \mathrm{~K}\right){ }^{102}$

Piperine (1-piperoylpiperidine) 37, is an alkaloid present in fruits of black pepper (Piper nigrum), long pepper

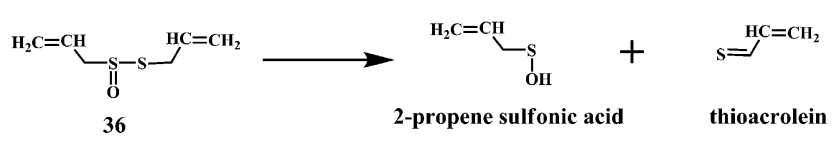

Scheme 11 Cope elimination products of allicilin 36 . a)<smiles>C=CCSS(=O)(=O)SCC=C</smiles>

b)

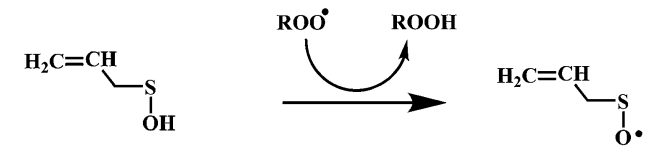

2-propene sulfonic acid

Scheme 12 Mechanism for the radical-trapping activity of (a) allicin and (b) 2-propenesulfenic acid.

(Piper longum), and other piper species (family: Piperaceae). Piperine possesses many pharmacological activities, including anti-inflammatory and analgesic effect, ${ }^{\mathbf{1 0 3}}$ anti-ulcer activities, ${ }^{104}$ antidepressant effect, ${ }^{105}$ cognitive enhancing effect, ${ }^{\mathbf{1 0 6}}$ cytoprotective effect, and antioxidant activity. ${ }^{\mathbf{1 0 7}}$ It is interesting to notice that, the higher concentration of piperine results in the increased production of the ${ }^{\circ} \mathrm{OH}$. Whereas, in low concentrations piperine acts as an antioxidant. ${ }^{108}$ Piperine demonstrates synergistic antioxidant activity by doubling the absorption of dietary curcumin $38 .^{109}$

Curcumin 38, a lipid soluble active principle of turmeric is a bis- $\alpha, \beta$-unsaturated $\beta$-diketone that exhibit's keto-enol tautomerism. ${ }^{\mathbf{1 1 0}}$ Curcumin 38, shows remarkable antioxidant

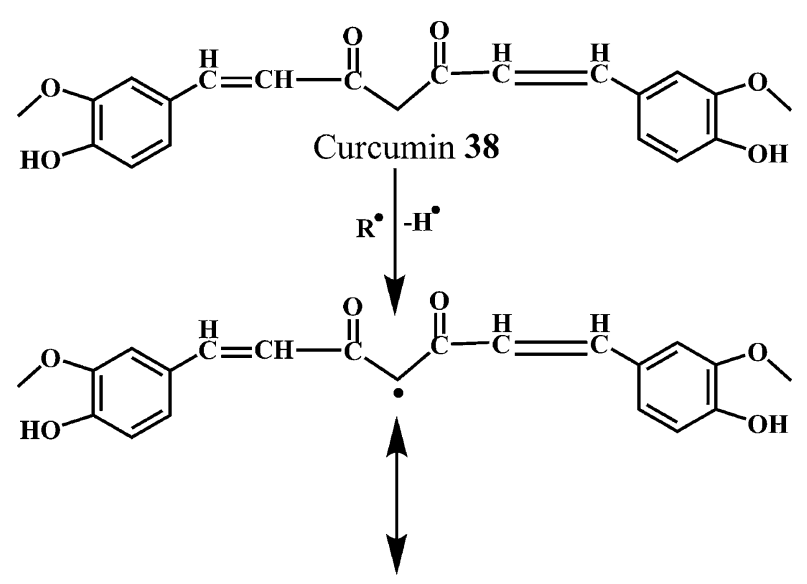<smiles>COc1cc(/C=C/C(=O)/C=C/C=C/C(=O)/C=C/C(=O)/C=C/c2ccc(O)c(OC)c2)ccc1O</smiles>

Scheme 13 Mechanism of radical scavenging activity of curcumin 38 initiated by methylenic moiety. 
activity, and it has been found to be an excellent free radical scavenger. ${ }^{111}$ Curcumin has a chain breaking antioxidant ability comparable to that of the vitamin $\mathrm{E}$.

As shown in the Schemes 13 and 14, the free radical scavenging activity of curcumin is correlated to the phenolic $\mathrm{OH}$ group and the $\mathrm{CH}_{2}$ group of the $\beta$-diketone moiety. The free radical can undergo electron transfer or abstract $\mathrm{H}$-atom from either of these two sites. However, pulse radiolysis and other biochemical methods credited the antioxidant activity of curcumin to its phenolic OH group. ${ }^{\mathbf{1 1 2}}$

The Scheme 14 depicts the mechanism for the autoxidation of curcumin initiated by hydrogen abstraction from one of the phenolic hydroxyl groups. ${ }^{113}$ The phenoxyl radical moves into the carbon chain leaving a quinone methide that is eventually quenched by the water molecules. The methide radical performs a 5-exo-cyclization with the double bond to give the cyclopentadione ring and generating the carbon-centered radical.

The reaction of curcumin with the molecular oxygen $\left(\mathrm{O}_{2}\right)$ results in the peroxyl radical. The peroxyl radical is then reduced to the hydroperoxide by abstracting a hydrogen atom from another curcumin molecule, propagating the autoxidation chain reaction. Subsequently, the hydroperoxide loses water and rearranges into the spiro-epoxide. The hydrolysis of the epoxide by the (water-derived) hydroxyl group results in the formation of the final bicyclopentadione product. ${ }^{114}$ It has been found that the copper complex of curcumin (curcumin-Cu(II)) show promising SOD activity, with improved antioxidant efficacy. ${ }^{115,116}$

The mechanism of the $\mathrm{O}_{2}{ }^{--}$scavenging activity of the curcumin-Cu(II) complex is depicted in the Scheme 15. When $\mathrm{O}_{2}{ }^{--}$ are allowed react with the curcumin-Cu(II) complex, a major fraction of $\mathrm{O}_{2}{ }^{\cdot-}$ reacts with $\mathrm{Cu}^{2+}$ moiety, while only a small fraction reacts with curcumin. The reaction causes reduction of $\mathrm{Cu}^{2+}$ to $\mathrm{Cu}^{+}$. The $\mathrm{Cu}^{+}$undergoes subsequent oxidation by another molecule of $\mathrm{O}_{2}{ }^{-}$, thereby regenerating the parent complex.

Therefore, the catalytic activity comes mainly from the reversible redox reactions within the $\mathrm{Cu}^{2+} / \mathrm{Cu}^{+}$couple in the complex. However, in presence of the excess $\mathrm{O}_{2}{ }^{\cdot-}$, the phenolic moiety undergoes oxidation resulting in the production of the phenoxyl radicals. Then these phenoxyl radicals can generate

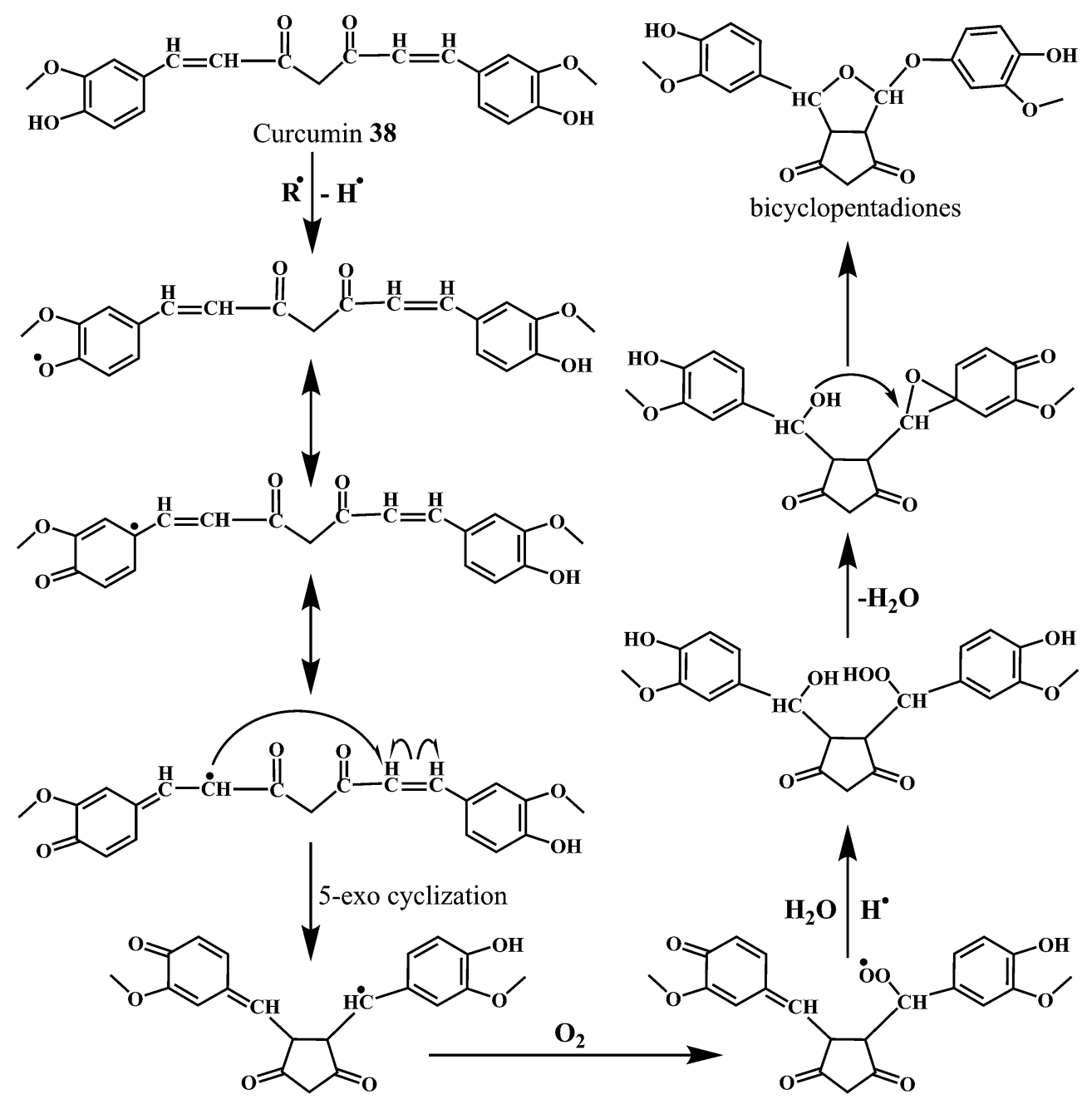

Scheme 14 Mechanism of radical scavenging activity of curcumin 38 initiated by phenolic moiety. 


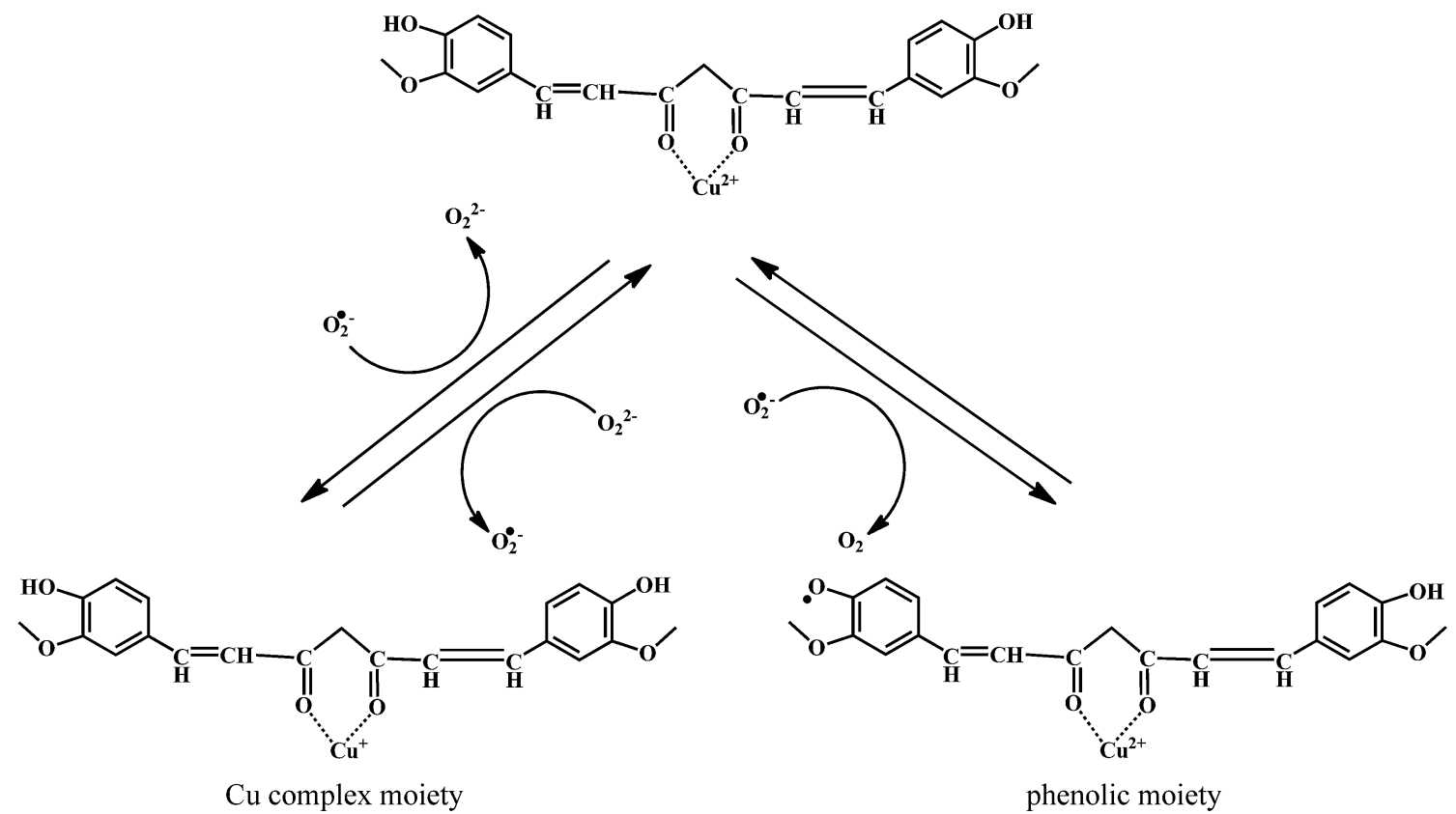

Scheme 15 Mechanism of radical scavenging activity of curcumin-Cu(॥) complex.

new products or react with reduced copper ions of the complex resulting in the regeneration of the complex.

\subsection{Physisological antioxidants}

Uric acid 39 in plasma, and GSH 40.<smiles>O=c1[nH]c(=O)c2[nH]c(=O)[nH]c2[nH]1</smiles>

39<smiles>N[C@@H](CCC(=O)N[C@@H](CS)C(=O)NCC(=O)O)C(=O)O</smiles>

40

Uric acid 39 in plasma possesses strong radical scavenging activity. ${ }^{117,118}$ Uric acid is the most abundant aqueous antioxidant found in humans. It contributes for as much as two-thirds of all free radical scavenging activities in the plasma. ${ }^{119}$ Uric acid is a powerful scavenger of carboncentered radicals and peroxyl radicals in the hydrophilic environment. However, it loses it's radical scavenging activity within lipid membranes. ${ }^{\mathbf{1 2 0}}$

Uric acid is an exceptional scavenger of peroxynitrite $\left(\mathrm{ONOO}^{-}\right)$in the extracellular fluid. ${ }^{121}$ However, it is important to note that the uric acid cannot scavenge the $\mathrm{O}_{2}{ }^{--}$. Moreover, uric acid requires the presence of ascorbic acid (Scheme 16) and thiols for the complete scavenging of peroxynitrites. Neither of these antioxidants (ascorbic acid, thiols) alone can prevent reaction of peroxynitrite with tetrahydrobiopterin, which leads to uncoupling of nitric oxide (NO') synthase. ${ }^{122}$ This indicates that the uric acid plays a crucial role in the scavenging of the peroxynitrite.

GSH 40 in cell cytosol, together with its related enzymes, comprises a system that maintains the intracellular reducing environment, which acts as primary defense against excessive generation of harmful ROS. ${ }^{\mathbf{1 2 3 , 1 2 4}}$ The oxygen radical scavenging activity of GSH directly expedites the ROS neutralization and the repair of ROS-induced damage. ${ }^{\mathbf{1 2 5}}$

As shown in the Scheme 17, three groups of enzymes can be identified in the GSH catalytic cycle: glutathione oxidase, glutathione reductase, and GSHPx. Glutathione oxidase and GSHPx catalyze the oxidation of GSH to GSH disulfide (GSSG). Whereas, glutathione reductase is responsible for the regeneration of GSH from GSSG in an NADPH-dependent process. ${ }^{126}$ Cells can produce GSSG or convert it to GSH by using NADPH in the presence of the glutathione reductase. However, the de nova synthesis of glutathione from its amino acid constituents is required for the elevation of glutathione as an adaptive response to oxidative stress. The presence of the sulfhydryl group in glutathione allows it to serve as an antioxidant. 
<smiles>O=c1[nH]c(=O)c2[nH]c(=O)[nH]c2[nH]1</smiles><smiles>Oc1nc(O)c2nc(O)[nH]c2n1</smiles><smiles>[R][C@H](C)C(C)C</smiles><smiles></smiles>

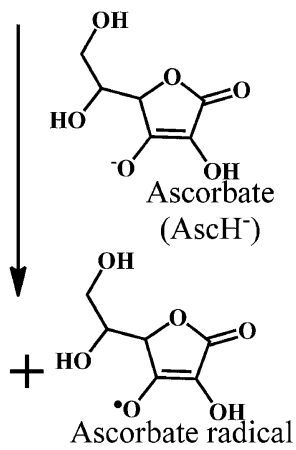

( $\mathrm{AscH})$

Scheme 16 Mechanism of radical scavenging activity of uric acid.

\subsection{Fungal antioxidants}

The microorganisms such as Ganoderma lucidum, ${ }^{\mathbf{1 2 7}}$ Ganoderma applanatum, Meripilus giganteus, Flammulina velutipes, and Endophytic Fungi ${ }^{\mathbf{1 2 8 , 1 2 9}}$ possess a very efficient antioxidative system consisting of enzymatic (peroxidases, laccase, catalase, and superoxide dismutase) and nonenzymatic elements (phenolic derivatives or polysaccharides).

The synthetic antioxidants are the second type of nonenzymatic antioxidants. Cinnamic acid derivatives ${ }^{130,131}$ 41, 42, melatonin 43, selegiline 44, are the few examples of the synthetic antioxidants. ${ }^{\mathbf{1 3 2 , 1 3 3}}$

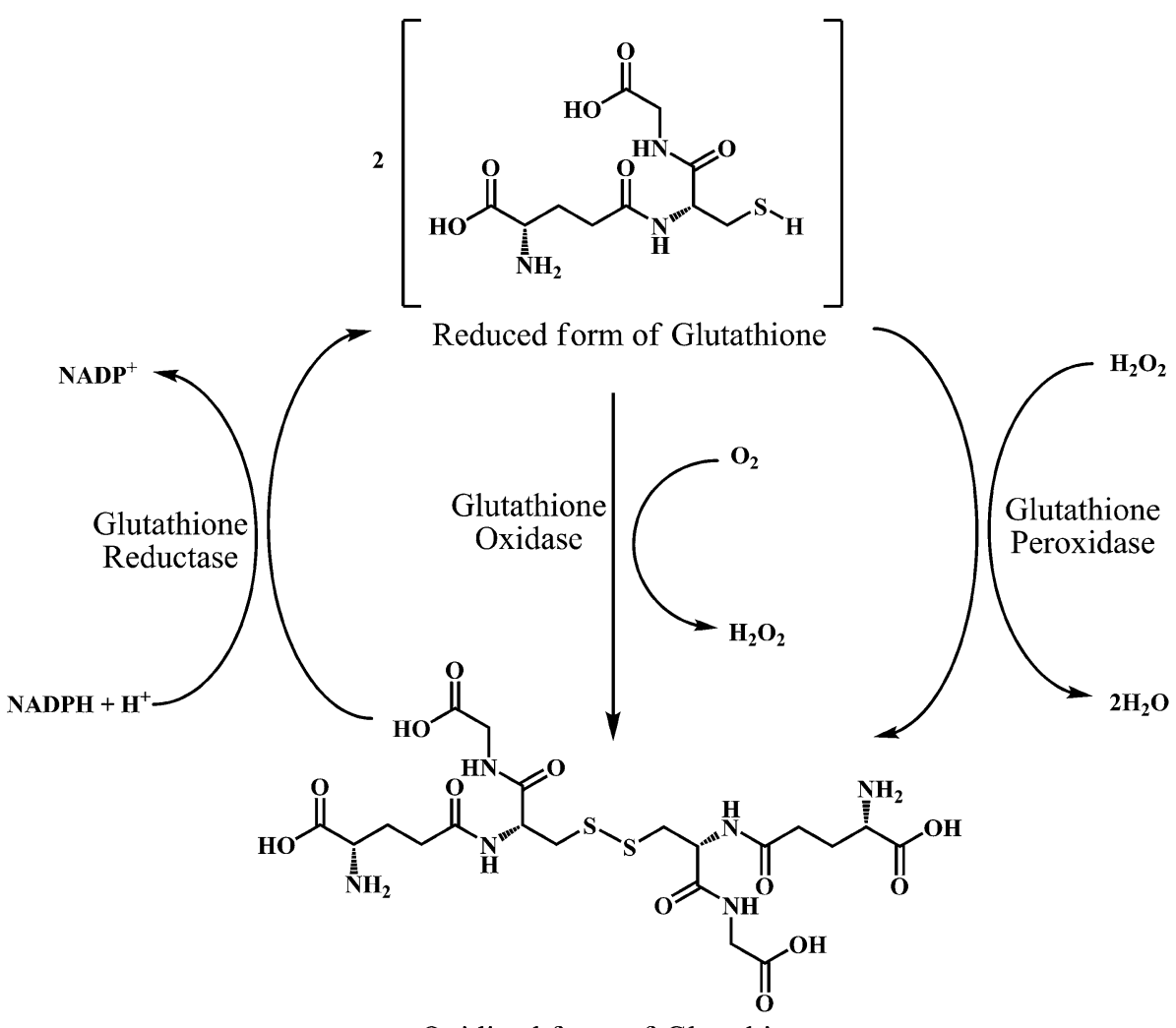

Scheme 17 Interconversion of glutathione in its reduced form (GSH) and oxidized form (GSSG) by the action of glutathione oxidase, glutathione reductase, and glutathione peroxidase enzymes. 
<smiles>COC(=O)C(Cc1ccccc1)NC(=O)/C=C/c1ccc(O)cc1</smiles><smiles>COC(=O)C(Cc1ccccc1)NC(=O)/C=C/c1ccc(O)c(O)c1</smiles>

42<smiles>COc1ccc2[nH]cc(CCNC(C)=O)c2c1</smiles>

43<smiles>C#CCN(C)C(C)Cc1ccccc1</smiles>

44

\section{In vitro methods for evaluation of antioxidant activity}

Various in vitro methods are available for the evaluation of antioxidant activity of different compounds. ${ }^{134-137}$

\subsection{Assay of superoxide anion radical scavenging activity}

SOD is an antioxidant enzyme involved in scavenging the ROS. ${ }^{138}$ SOD converts the $\mathrm{O}_{2}{ }^{--}$to $\mathrm{H}_{2} \mathrm{O}_{2}$. The $\mathrm{H}_{2} \mathrm{O}_{2}$ is then converted to the $\mathrm{O}_{2}$ and $\mathrm{H}_{2} \mathrm{O}$ in the reaction catalyzed by GSHPx and CAT. ${ }^{139}$ There are several classes of SOD, which include intracellular copper, zinc SOD $\left(\mathrm{Cu}, \mathrm{Zn} \mathrm{SOD} / \mathrm{SOD}_{1}\right)$, mitochondrial manganese SOD ( $\left.\mathrm{Mn} \mathrm{SOD} / \mathrm{SOD}_{2}\right)$, and extracellular $\mathrm{Cu}$, Zn SOD (EC SOD/SOD ${ }_{3}$ ).

The method for the evaluation of the $\mathrm{O}_{2}{ }^{\cdot-}$ scavenging activity of antioxidants is explained here by using PMS-NADH-NBT system, which is composed of $N$-methylphenazine methosulphate (PMS), nitroblue tetrazolium chloride (NBT), and NADH (a reduced form of nicotineamide-adenine-dinucleotide).
As shown in the Scheme 18 , the $\mathrm{O}_{2}{ }^{--}$produced in the coupling reaction of PMS-NADH in presence of dissolved oxygen reduces NBT. The decrease of absorbance at $560 \mathrm{~nm}$ with antioxidant indicates the consumption of $\mathrm{O}_{2}{ }^{--}$in the reaction mixture. The $\mathrm{O}_{2}{ }^{--}$scavenging activity can be measured as described by Robak and Gryglewski. ${ }^{140}$ Gallic acid, BHA, ascorbic acid, $\alpha$-tocopherol, and curcumin can be used as positive controls in this assay.

\subsection{Assay of 2,2-diphenyl-1-picrylhydrazyl (DPPH) free radical scavenging activity}

Evaluation of the antioxidant activity of any compound can be carried out either by in vitro or in vivo models. ${ }^{141,142} \mathrm{DPPH}$ is a stable free radical that can accept an electron or hydrogen radical to become a stable diamagnetic molecule.

Due to its odd electron, the methanolic solution of DPPH shows a strong absorption band at $517 \mathrm{~nm}$. As shown in the Scheme 19, the DPPH radical reacts with suitable reducing agent producing new bond, thus changing the color of solution. The solution loses color with the increase in the concentration of antioxidant as the electrons taken up by DPPH radical from the antioxidant. ${ }^{143,144}$ Such reactivity has been used to test the ability of compounds/plant extracts to act as free radical scavengers. ${ }^{145}$ Reduction of the DPPH radicals can be monitored spectrophotometrically by the decrease in absorbance at 517 nm.

\subsection{Assay for total reactive oxygen potential (TRAP) and total antioxidant reactivity (TAR)}

Luminol enhanced chemiluminescence is used to measure TRAP and TAR. ${ }^{146,147}$ When the luminol is allowed to react with the free radical source, a steady chemiluminescence is observed that can be directly correlated to the rate of luminol oxidation. ${ }^{148}$ The addition of free radical scavengers reduces the chemiluminescence intensity. ${ }^{149}$ The effect of antioxidants on the induced chemiluminescence intensity of luminol by radicals derived from the thermolysis of 2,2'-azobis-2amidinopropanedihydrochloride (AAPH) can be employed to monitor the TRAP and TAR levels. ${ }^{150}$

As shown in the Scheme 20, the AAPH undergoes thermal decomposition in solution to produce two carbon-centered amidino propane (AP) radicals, which can add $\mathrm{O}_{2}$ to form peroxyl radicals. However, the carbon-centered radicals usually predominate. ${ }^{151}$ The amidino propane (AP) radical takes up a proton from luminol to produce a luminol radical. The luminol radical reacts with de-protonated $\mathrm{H}_{2} \mathrm{O}_{2}$ to yield a short-lived hydroperoxide intermediate $\left(\mathrm{LO}_{2} \mathrm{H}^{-}\right)$, which rapidly decomposes into the excited state 3 -aminophthalic acid ( $\left.\mathrm{AP}^{*}\right)$. The $\mathrm{AP}^{*}$ loses energy in the form of chemiluminescence to give ground state 3-aminophthalic acid. ${ }^{152}$

\subsection{In vitro antioxidant evaluation by phospholipids peroxidation}

Lipid peroxidation is an oxidative degradation of lipids. ${ }^{153}$ In this process, the free radical takes up the electrons from the lipids in cell membranes, which results in the cell damage. ${ }^{154,155}$ 


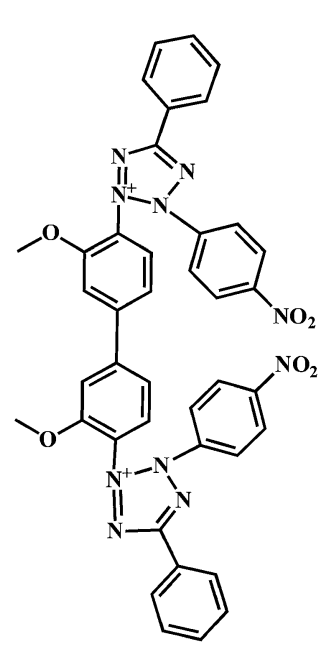

$\mathrm{NBT}^{2+}$
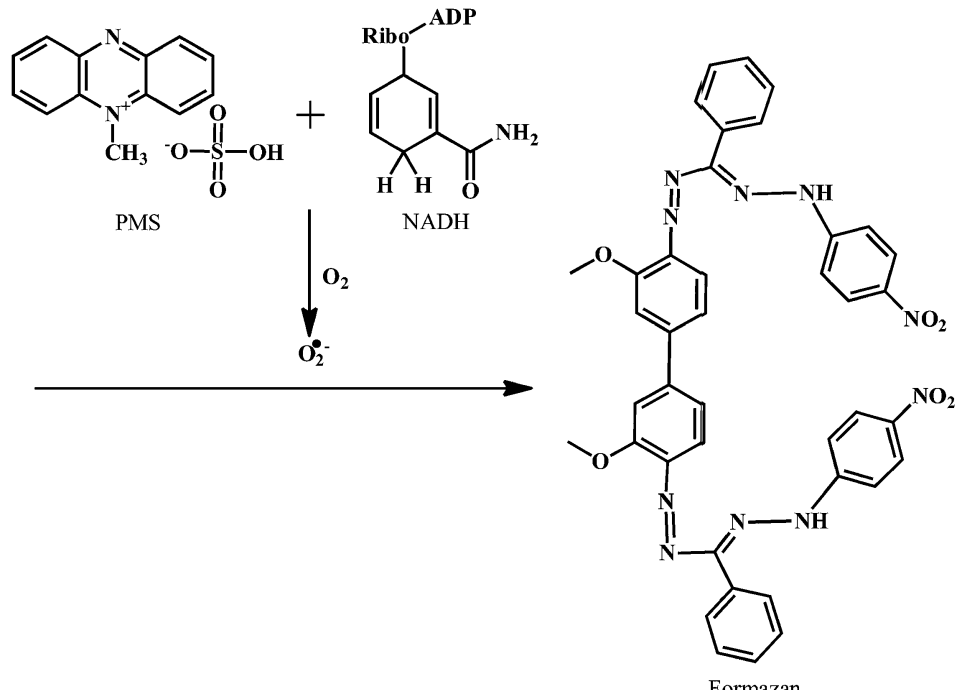

Scheme 18 Reduction of NBT by superoxide anion radical produced in PMS-NADH reaction.

The tentative mechanism for this free radical chain reaction involved in the phospholipid peroxidation is depicted in the Scheme 21.

The activity of test compound to inhibit peroxidation of membrane lipids at $\mathrm{pH} 7.4$ is tested using phospholipids. The interference of the test drug with color development is determined by adding a previously determined concentration of the test compound to the TBA reagents and used to determine the extent of peroxidation of animal phospholipids. ${ }^{156,157}$ In this assay, the antioxidant activity is a measure of concentrationdependent inhibition of a phospholipid peroxidation.

\subsection{In vitro antioxidant evaluation by deoxyribose assay}

The ${ }^{\circ} \mathrm{OH}$ in presence of ascorbic acid attack the sugar deoxyribose to generate the product that on heating with thiobarbituric acid (TBA) or thiobarbiturate reactive substances (TBARS), at low $\mathrm{pH}$, yield a chromogen. Therefore, the deoxyribose assay can be used to detect ${ }^{\circ} \mathrm{OH}$ scavenging activity of test compounds.

The reaction of deoxyribose and ${ }^{\circ} \mathrm{OH}$ has been discussed extensively in the literature. ${ }^{158,159}$ The ${ }^{\circ} \mathrm{OH}$ attack deoxyribose to form products that react with TBA upon heating at low $\mathrm{pH}$ and yield a pink chromogen. Scheme 22 depicts the proposed mechanism of chromogen formation from reaction of deoxyribose and ${ }^{\circ} \mathrm{OH}$ followed by reaction with TBARS.

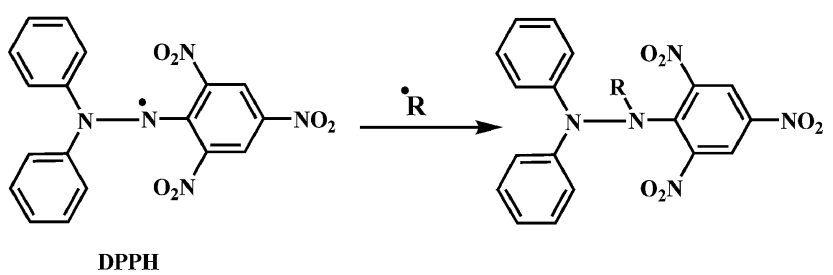

Scheme 19 Reaction of DPPH radical with other radicals $\left({ }^{\circ} \mathrm{R}={ }^{\cdot} \mathrm{H}\right.$, alkyl radical etc.)
In general, the in vivo assays for testing potential antioxidants are more expensive because they require complex cellular testing systems or full clinical trials. However, it is very important to proceed to cellular assays after screening antioxidant activity with an in vitro method in order to obtain information on some aspects like uptake, bioavailability, and metabolism. ${ }^{\mathbf{1 6 0}}$ The new definition of an antioxidant, a redox-active compound or mixture able to modulate the redox status of the cell, makes it critical to use in vivo assays in order to evaluate the antioxidant activity of a compound. ${ }^{\mathbf{1 6 1}}$ There are several reports on the in vivo assays for the evaluation of the antioxidant activity. ${ }^{162,163}$ However, we have limited the scope of this review to the in vitro assays for the evaluation of the antioxidant activities of natural antioxidants. There are several other reports, which elaborate the advantages and disadvantages of various methods for the evaluation of antioxidant activity. ${ }^{\mathbf{1 6 4 , 1 6 5}}$

\section{Current trends and future directions}

In recent years, there has been upsurge in the novel approaches for the study of free radicals and antioxidants in relation with the improvement of human health. Multiple studies have showed that the neuronal and behavioral changes occur with ageing, even in the absence of degenerative disease. Recent studies have found the association between the lower status of dietary antioxidants and decline in the cognitive function. The evidences from the experimental, clinical, and epidemiological studies indicate that the consumption of foods containing high levels of dietary antioxidants may prevent or reduce the risk of cognitive deterioration. Tempol, an example of a new class of SOD mimetic drugs, alleviates acute and chronic pain. These drugs substantially reduce the tissue damage incurred by inflammation. The speculations of the relations between radical damage and disease conditions need to the support of by more secure data. The knowledge on the mechanisms of various 


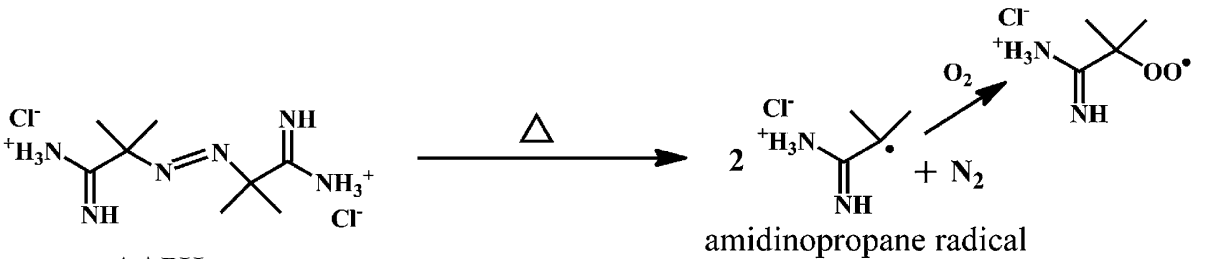

Scheme 20 Mechanism of AAPH induced chemiluminescence of luminol.

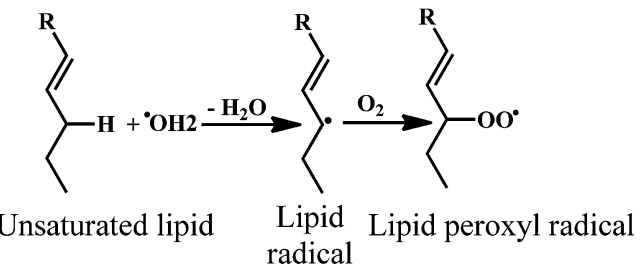

Scheme 21 Phospholipid peroxidation of unsaturated lipids.

physiological radical reactions and the mechanisms of the antioxidants in scavenging those free radicals will open up the path for more potent drug molecules.

Many investigators found that, increasing the level of defense mechanisms against oxidative stress could extend an organism's health span. Therefore, few setbacks in the antioxidant research with the molecules showing strong antioxidant activity in vitro and non-antioxidant effects in cells and tissues

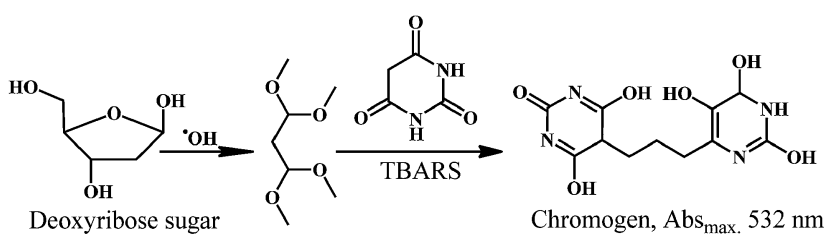

Scheme 22 Reaction of deoxyribose sugar with hydroxyl radical in presence of TBARS. should not discourage the important research in this field. Finally, the collective effort is must be undertaken for the understanding of the mechanisms in the free radical scavenging activities of known antioxidants to derive the potent antioxidants.

\section{Conclusion}

ROS, the radical derivatives of oxygen are the most important free radical in biological systems. The ROS are the harmful byproducts generated during the normal cellular functions. Increasing intake of natural antioxidants may help to maintain a tolerable antioxidant status, perhaps the normal physiological functioning. The reported chemical evidence suggests that the dietary antioxidants help in the disease prevention. The antioxidant compounds react in one-electron reactions with free radicals in vitro and prevent the oxidative damage. Therefore, it is very important to understand the reaction mechanism of antioxidant with the free radicals. The reaction mechanisms can be used to evaluate the antioxidant activity of various naturally occurring antioxidant compounds. This review elaborates the mechanism of action of the natural antioxidant compounds and assays for the evaluation of their antioxidant activities. The reaction mechanisms of the antioxidant assays are briefly discussed (165 references). The scope of this article is limited to the natural antioxidants and the in vitro assays for evaluation of their antioxidant properties. 


\section{Conflicts of interest}

The author declares no conflict of interest.

\section{Abbreviations}

$\begin{array}{ll}\text { ROS } & \text { Reactive oxygen species } \\ \text { RNS } & \text { Reactive nitrogen species } \\ \text { SOD } & \text { Superoxide dismutase } \\ \text { CAT } & \text { Catalase } \\ \text { GSHPx } & \text { Glutathione peroxidase } \\ \text { MPO } & \text { Myeloperoxidase } \\ \mathrm{O}_{2}{ }^{\cdot-} & \text { Superoxide anion radical } \\ \mathrm{H}_{2} \mathrm{O}_{2} & \text { Hydrogen peroxide } \\ { }^{\mathrm{OH}} & \text { Hydroxyl radical } \\ \text { EDRF } & \text { Endothelium derived relaxation factor } \\ \text { CHD } & \text { Coronary heart disease } \\ \text { PUFA } & \text { Polyunsaturated fatty acids } \\ \text { DNA } & \text { Deoxyribonucleic acid } \\ \text { Prx } & \text { Peroxiredoxin } \\ \text { LDL } & \text { Low density lipoprotein } \\ \text { GSH } & \text { Glutathione } \\ \text { GSSG } & \text { Glutathione disulfide } \\ \text { PMS } & N \text {-Methylphenazine methosulphate } \\ \text { NBT } & \text { Nitroblue tetrazolium chloride } \\ \text { DPPH } & \text { 2,2-Diphenyl-1-picrylhydrazyl } \\ \text { TRAP } & \text { Total reactive oxygen potential } \\ \text { TAR } & \text { Total antioxidant reactivity } \\ \text { AAPH } & \text { 2,2'-Azobis-2-amidinopropanedihydrochloride } \\ \text { TBA } & \text { Thiobarbituric acid } \\ \text { TBARS } & \text { Thiobarbiturate reactive substances }\end{array}$

\section{Acknowledgements}

This research was supported by the Hallym University Research Fund (HRF-201411-014).

\section{Notes and references}

1 I. S. Young and J. V. Woodside, J. Clin. Pathol., 2001, 54, 176-186.

2 K. Bagchi and S. Puri, East. Meditrr. Health. J., 1998, 4, 350360.

3 Y. W. Kim and T. V. Byzova, Blood, 2014, 123, 625-631.

4 H. Sies, Exp. Physiol., 1997, 82, 291-295.

5 D. K. Pal and S. B. Nimse, Asian J. Chem., 2006, 13, 3004-3008.

6 C. E. Thomas and B. Kalyanaraman, in Oxygen Radical and the Disease Process, Harvard Academic Publishers, Netherlands, 1997.

7 F. Shahidi and Y. Zhong, Eur. J. Lipid Sci. Technol., 2010, 112, 930-940.

8 B. M. Babior, Blood, 1999, 93, 1464-1476.

$9 \mathrm{~J}$. A. Knight, in Free radicals, antioxidants, aging and disease, AACC Press, Washington, 1999.

10 L. Zhu, C. Gunn and J. S. Beckman, Arch. Biochem. Biophys., 1992, 298, 452-457.
11 S. Moncanda, R. M. J. Palmer and E. A. Higgs, Pharmacol. Rev., 1991, 43, 109-142.

12 C. F. Nathan and J. B. Hibbs Jr, Curr. Opin. Immunol., 1991, 3, 65-70.

13 F. Shahidi and Y. Zhong, Chem. Soc. Rev., 2010, 39, 40674079.

14 A. V. Rao and S. Agarwal, Nutr. Res., 1999, 19, 305-326.

15 A. M. Jenkinson, A. R. Collins, S. J. Duthie, K. W. J. Wahle and G. G. Duthie, FASEB J., 1999, 13, 2138-2142.

16 Y. Park, S. Nam, H. J. Yi, H. J. Hong and M. Lee, Nutr. Res., 2009, 29, 812-818.

17 H. Esterbauer, M. Dieber-Rotheneder, G. Waeg, G. Striegl and G. Juergens, Chem. Res. Toxicol., 1990, 3, 77-92.

18 W. A. Pryor and N. A. Porter, Free Radical Biol. Med., 1990, 8, 541-543.

19 T. P. A. Devasgayam, K. K. Boloor and T. Ramasarma, Indian J Biochem. Biophys., 2003, 40, 300-308.

20 H. Esterbauer, R. J. Schanr and H. Zollen, Free Radical Biol. Med., 1991, 11, 81-121.

21 M. Dizdaroglu, P. Jaruga, M. Birincioglu and H. Rodriguez, Free Radical Biol. Med., 2002, 32, 1102-1115.

22 B. Halliwell and J. M. C. Gutteridge, in Free radicals in biology and medicine, Oxford University Press, Oxford, 4th edn, 2007.

23 C. von Sonntag, in Free-radical-induced DNA damage and its repair, Springer, Hiedelberg, 2006.

24 M. Dizdaroglu, Mutat. Res., 1992, 275, 331-342.

25 A. P. Breen and J. A. Murphy, Free Radical Biol. Med., 1995, 18, 1033-1077.

26 M. Dizdaroglu and P. Jaruga, Free Radical Res., 2012, 46, 382-419.

27 J. A. Simpson, S. Narita, S. Gieseg, S. Gebicki, J. M. Gebicki and R. T. Dean, Biochem. J., 1992, 282, 621-624.

28 S. Gieseg, S. Duggan and J. M. Gebicki, Biochem. J., 2000, 350, 215-218.

29 E. R. Stadtman, Free Radical Biol. Med., 1990, 9, 315-325.

30 M. S. Cooke, M. D. Evans, M. Dizdaroglu and J. Lunec, FASEB J., 2003, 17, 1195-1214.

31 P. M. Kris-Etherton, K. D. Hecker, A. Bonanome, S. M. Coval, A. E. Binkoski, K. F. Hilpert, A. E. Griel and T. D. Etherton, Am. J. Med., 2002, 113, 71-88.

32 D. Pal, S. Banerjee and A. Ghosh, J. Adv. Pharm. Technol. Res., 2012, 3, 16-24.

33 E. A. Lissi, M. Salim-Hanna, C. Pascual and M. Del-Castillo, Free Radical Biol. Med., 1995, 18, 153-158.

34 M. Koruk, S. Taysi, M. C. Savas, O. Yilmaz, F. Akcay and M. Karakok, Ann. Clin. Lab. Sci., 2004, 34, 57-62.

35 D. R. Gough and T. G. Cotter, Cell Death Dis., 2011, 2, e213. 36 C. D. Zhan, R. K. Sindhu, J. Pang, A. Ehdaie and N. D. Vaziri, J. Hypertens., 2004, 22, 2025-2033.

37 J. R. Stone and S. Yang, Antioxid. Redox Signaling, 2006, 8, 243-270.

38 E. Cabiscol, J. Tamarit and J. Ros, Int. Microbiol., 2000, 3, 38.

39 J. R. Arthur, Cell Mol. Life Sci., 2000, 57, 1825-1835.

40 J. M. Matés, Toxicology, 2000, 153, 83-104. 
41 M. Valko, C. J. Rhodes, J. Moncol, M. Izakovic and M. Mazur, Chem.-Biol. Interact., 2006, 160, 1-40.

42 J. M. Matés, C. Perez-Gomez and I. N. De Castro, Clin. Biochem., 1999, 32, 595-603.

43 S. Tafazoli, J. S. Wright and P. J. O'Brien, Chem. Res. Toxicol., 2005, 18, 1567-1574.

44 A. Vojdani, M. Bazargan, E. Vojdani and J. Wright, Cancer. Detect. Prev., 2000, 24, 508-523.

45 P. K. Witting, J. M. Upston and R. Stocker, Biochemistry, 1997, 36, 1251-1258.

46 P. Morlière, L. K. Patterson, C. M. M. Santos, A. M. S. Silva, J. Mazière, P. Filipe, A. Gomes, E. Fernandes, M. B. Q. Garciah and R. Santusc, Org. Biomol. Chem., 2012, 10, 2068-2076.

47 R. Stocker, V. W. Boury and B. Frei, Proc. Natl. Acad. Sci. U. S. A., 1991, 88, 1646-1650.

48 E. Niki, Free Radical Biol. Med., 2014, 66, 3-12.

49 E. Niki, Am. J. Clin. Nutr., 1991, 54, 1119S-1124S.

50 K. L. Retsky, M. W. Freeman and B. Frei, J. Biol. Chem., 1993, 268, 1304-1309.

51 C. Oh, M. Li, E. Kim, J. S. Park, J. Lee and S. W. Ham, Bull. Korean Chem. Soc., 2010, 31, 3513-3514.

52 B. R. Monaghan and F. O. Schmitt, J. Biol. Chem., 1932, 96, 387-395.

53 R. S. Parker, FASEB J., 1996, 10, 542-551.

54 A. V. Vieira, W. J. Schneider and P. M. Vieira, J. Endocrinol., 1995, 146, 201-207.

55 M. A. Livrea, L. Tesoriere, A. Bongiorno, A. M. Pintaudi, M. Ciaccio and A. Riccio, Free Radical Biol. Med., 1995, 18, 401-409.

56 L. Tesoriere, D. D'arpa, R. Re and M. A. Livrea, Arch. Biochem. Biophys., 1997, 343, 13-18.

57 P. G. Pietta, J. Nat. Prod., 2000, 63, 1035-1042.

58 C. A. Rice-Evans, N. J. Miller and G. Paganga, Free Radical Biol. Med., 1996, 20, 933-956.

59 P. Pietta, J. Nat. Prod., 2000, 63, 1035-1042.

60 R. J. Nijveldt, E. van Nood, D. E. C. van Hoorn, P. G. Boelens, K. van Norren and P. A. van Leeuwen, Am. J. Clin. Nutr., 2001, 74, 418-425.

61 A. Russo, R. Acquaviva, A. Campisi, V. Sorrenti, C. D. Giacomo, G. Virgata, M. L. Barcellona and A. Vanella, Cell Biol. Toxicol., 2000, 16, 91-98.

62 F. V. Rubens de Souza and F. W. De Giovani, Redox Rep., 2004, 9, 97-104.

63 T. Armida, T. Maurizio, T. Andrea and B. Sergio, J. Mol. Struct., 2005, 44, 759-766.

64 J. Zhou, L. F. Wang, J. Y. Wang and N. Tang, Transition Met. Chem., 2001, 26, 57-93.

65 V. Krishnamachari, L. H. Levine and P. W. Pareá, J. Agric. Food Chem., 2002, 50, 4357-4363.

66 A. Das, J. H. Wang and E. J. Lien, Prog. Drug Res., 1994, 42, 133-166.

67 S. J. Duthie, J. W. ohnson and V. L. Dobson, Mutat. Res., 1997, 390, 141-151.

68 T. Jun, Z. Liancai and W. Bochu, Int. J. Pharmacol., 2007, 3, 19-26.
69 D. Galaris and A. Evangelou, Crit. Rev. Oncol. Hematol, 2002, 42, 93-103.

70 S. S. Pekkarinen, I. M. Heinonen and A. I. Hopia, J. Sci. Food Agric., 1999, 79, 499-506.

71 M. G. Miguel, J. Appl. Pharm. Sci., 2011, 01, 07-15.

72 A. Castañeda-Ovando, M. L. Pacheco-Hernández, M. E. Páez-Hernández, J. A. Rodríguez and G.-C. Vidal, Food Chem., 2009, 113, 859-871.

73 R. J. Nijveldt, E. van Nood, D. E. C. van Hoorn, P. G. Boelens, K. van Norren and P. A. M. van Leeuwen, Am. J. Clin. Nutr., 2001, 74, 418-425.

74 S. A. van Acker, D. J. van den Berg, M. N. Tromp, D. H. Griffioen, W. P. van Bennekom, W. J. van der Vijgh and A. Bast, Free Radical Biol. Med., 1996, 20, 331-342.

75 W. Stahl and H. Sies, Mol. Aspects Med., 2003, 24, 345-351. 76 L. Mueller and V. Boehm, Molecules, 2011, 16, 1055-1069. 77 J. A. Olson and N. I. Krinsky, FASEB J., 1995, 9, 1547-1550. 78 H. Sies and W. Stahl, Am. J. Clin. Nutr., 1995, 62, 1315S$1321 \mathrm{~s}$.

79 W. Stahl and H. Sies, Mol. Aspects Med., 2003, 24, 345-351. 80 J. G. Erhardt, C. Meisner, J. C. Bode and C. Bode, Am. J. Clin. Nutr., 2003, 78, 1219-1224.

81 A. V. Rao and L. G. Rao, Pharmacol. Res., 2007, 55, 207-216. 82 N. I. Krinsky and E. J. Johnson, Mol. Aspects Med., 2005, 26, 459-516.

83 G. Riccioni, Curr. Atheroscler. Rep., 2009, 11, 434-439.

84 P. Di Mascio, S. Kaiser and H. Sies, Arch. Biochem. Biophys., 1989, 274, 532-538.

85 G. Levin, M. Yeshurun and S. Mokady, Nutr. Cancer, 1997, 27, 293-297.

86 V. Böhm, N. L. Puspitasari-Nienaber, M. G. Ferruzzi and S. J. Schwartz, J. Agric. Food Chem., 2002, 50, 221-226.

87 M. F. Andreasen, A. Landbo, L. P. Christensen, A. Hansen and A. S. Meyer, J. Agric. Food Chem., 2001, 49, 4090-4096.

88 F. Natella, M. Nardini, M. Di Filici and C. Scaccini, J. Agric. Food Chem., 1999, 47, 1453-1459.

89 A. S. Meyer, J. L. Donovan, D. A. Pearson, A. L. Waterhouse and E. N. Frankel, J. Agric. Food Chem., 1998, 46, 1783-1787.

90 V. P. Menon and A. R. Sudheer, Adv. Exp. Med. Biol., 2007, 595, 105-125.

91 J. S. Wright, J. Mol. Struct.: THEOCHEM, 2002, 59, 207-217. 92 N. J. Miller, C. Castelluccio, L. Tijburg and C. Rice-Evans, FEBS Lett., 1996, 392, 40-44.

93 M. Shiraki, Y. Hara, T. Osawa, H. Kumon, T. Nakayama and S. Kawakishi, Mutat. Res., 1994, 323, 29-34.

94 L. K. Leung, Y. Su, R. Chen, Z. Zhang, Y. Huang and Z. Y. Chen, J. Nutr., 2001, 131, 2248-2251.

95 S. Ankri, T. Miron, A. Rabinkov, M. Wilchek and D. Mirelman, Antimicrob. Agents Chemother., 1997, 41, 2286-2288.

96 K. C. Agarwal, Med. Res. Rev., 1996, 16, 111-124.

97 K. Prasad, V. A. Laxdal, M. Yu and B. L. Raney, Mol. Cell. Biochem., 1995, 148, 183-189.

98 V. Vaidya, K. U. Ingold and D. A. Pratt, Angew. Chem., Int. Ed., 2009, 48, 157-159.

99 E. Block, Angew. Chem., Int. Ed., 1992, 31, 1135-1178. 
100 P. T. Lynett, K. Butts, V. Vaidya, G. E. Garretta and D. A. Pratt, Org. Biomol. Chem., 2011, 9, 3320-3330.

101 R. Amorati, P. T. Lynett, L. Valgimigli and D. A. Pratt, Chem.-Eur. J., 2012, 18, 6370-6379.

102 A. Galano and M. Francisco-Marquez, J. Phys. Chem. B, 2009, 113, 16077-16081.

103 S. K. Gupta, P. Bansal, R. K. Bhardwaj and T. Velpandian, Pharmacol. Res., 2000, 41, 657-662.

104 Y. F. Bai and H. Xu, Acta Pharmacol. Sin., 2000, 21, 357-359. 105 S. A. Lee, S. S. Hong, X. H. Han, J. S. Hwang, G. J. Oh, K. S. Lee, M. K. Lee, B. Y. Hwang and J. S. Ro, Chem. Pharm. Bull., 2005, 53, 832-835.

$106 \mathrm{~J}$. Wattanathorn, P. Chonpathompikunlert, S. Muchimapura, A. Priprem and O. Tankamnerdthai, Food Chem. Toxicol., 2008, 46, 3106-3110.

107 K. Selvendiran, J. P. Singh, K. B. Krishnan and D. Sakthisekaran, Fitoterapia, 2003, 74, 109-115.

108 G. Shoba, D. Joy, T. Joseph, M. Majeed, R. Rajendran and P. S. Srinivas, Planta Med., 1998, 64, 353-356.

109 P. Anand, A. B. Kunnumakkara, R. A. Newman and B. B. Aggarwal, Mol. Pharm., 2007, 4, 807-818.

110 P. Ananda, S. G. Thomas, A. B. Kunnumakkara, C. Sundaram, K. B. Harikumar, B. Sung, S. T. Tharakan, K. Misra, I. K. Priyadarsini, K. N. Rajasekharan and B. B. Aggarwal, Biochem. Pharmacol., 2008, 76, 1590-1611.

111 K. I. Priyadarsini, D. K. Maity, G. H. Naik, M. Sudheer, M. K. Unnikrishnan, J. G. Satav and H. Mohan, Free Radical Biol. Med., 2003, 35, 475-484.

112 M. Salem, S. Rohanib and E. R. Gillies, RSC Adv., 2014, 4, 10815-10829.

113 O. N. Gordon and C. Schneider, Trends Mol. Med., 2012, 18, 361-363.

114 M. Griesser, V. Pistis, T. Suzuki, N. Tejera, D. A. Pratt and C. Schneider, J. Biol. Chem., 2011, 286, 1114-1124.

115 N. Sreejayan, M. N. A. Rao, K. I. Priyadarsini and T. P. A. Devasagayam, Int. J. Pharmacol., 1997, 151, 127-130.

116 A. Barik, B. Mishra, L. Shen, H. Mohan, R. M. Kadam, S. Dutta, H. Zhang and K. I. Priyadarsini, Free Radical Biol. Med., 2005, 39, 811-822.

117 B. Stinefelt, S. S. Leonard, K. P. Blemings, X. Shi and H. Klandorf, Ann. Clin. Lab. Sci., 2005, 35, 37-45.

118 A. Galano and J. R. Alvarez-Idaboy, RSC Adv., 2011, 1, 17631771.

119 W. S. Warning, QJM: An International Journal of Medicine, 2002, 95, 691-693.

120 S. Muraoka and T. Miura, Pharmacol. Toxicol., 2003, 93, 284-289.

121 G. L. Squadrito, R. Cueto, A. E. Splenser, A. Valavanidis, H. Zhang, R. M. Uppu and W. A. Pryor, Arch. Biochem. Biophys., 2000, 376, 333-337.

122 N. Kuzkaya, N. Weissmann, D. G. Harrison and S. Dikalov, Biochem. Pharmacol., 2005, 70, 343-354.

123 P. Ahmadpoor, E. Eftekhar, J. Nourooz-Zadeh, H. Servat, K. Makhdoomi and A. Ghafari, Iran J. Kidney Dis., 2009, 3, 22-27.

124 R. B. Pereira, C. Sousa, A. Costa, P. B. Andrade and P. Valentão, Molecules, 2013, 18, 8858-8872.
125 A. Pastore, G. Federici, E. Bertini and F. Piemonte, Clin. Chim. Acta, 2003, 333, 19-39.

126 P. C. Huber and W. P. Almeida, Quim. Nova, 2008, 31, 11701179.

127 M. A. Karaman, N. M. Mimica-Dukić and M. N. Matavulj, Arch. Biol. Sci., 2005, 57, 93-100.

128 R. B. Jalgaonwala, B. V. Mohite and R. T. Mahajan, J. Microbiol. Biotechnol. Res., 2011, 1, 21-32.

129 N. Sadrati, H. Daoud, A. Zerroug, S. Dahamna and S. Bouharati, J. Plant Prot. Res., 2013, 53, 128-136.

130 F. Vélez-González, D. Ortegón-Reyna, A. A. RamosOrganillo, A. L. Peraza-Campos, M. T. Sumaya-Martínez, R. Tapia-Benavides and F. J. Martínez-Martíneza, ARKIVOC, 2008, V, 55-64.

131 S. Lee, J. Han, H. Kim, E. Kim, T. Jeong, W. S. Lee and K. Cho, Bioorg. Med. Chem. Lett., 2004, 14, 4677-4681.

132 F. Natella, M. Nardini, M. D. Felice and C. Scaccini, J. Agric. Food Chem., 1999, 47, 1453-1459.

133 D. Point, P. Coudert, F. Leal, C. Rubat, V. Sautou-Miranda, J. Chopineau and J. Couquelet, Il Farmaco, 1998, 53, 85-88.

134 D. Krishnaiah, R. Sarbatly and R. Nithyanandam, Food Bioprod. Process., 2011, 89, 217-233.

135 D. Pal and S. Mitra, J. Adv. Pharm. Technol. Res., 2010, 1, 268-272.

136 M. N. Alam, N. J. Bristi and M. Rafiquzzaman, Saudi Pharm. J., 2013, 21, 143-152.

137 M. Carocho and I. C. F. R. Ferreira, Food Chem. Toxicol., 2013, 51, 15-25.

138 J. A. Imlay, Nat. Rev. Microbiol., 2013, 11, 443-454.

139 A. Meyer-Isaksen, Trends Food Sci. Technol., 1995, 6, 300304.

140 J. Robak and R. J. Gryglewski, Flavonoids are scavengers of superoxide anions, Biochem. Pharmacol., 1988, 37, 837-841.

141 C. W. Choi, S. C. Kim, S. S. Hwang, B. K. Choi, H. J. Ahn, M. Y. Lee, S. H. Park and S. K. Kim, Plant Sci., 2002, 163, 1161-1168.

142 C. Sánchez-Moreno, Food Sci. Technol. Int., 2002, 8, 121137.

143 C. A. Calliste, P. Trouillas, D. P. Allais, A. Simon and J. L. Duroux, J. Agric. Food Chem., 2001, 49, 3321-3327.

144 C. A. Calliste, D. Kozlowski, J. L. Duroux, Y. Champavier, A. J. Chulia and P. Trouillas, Food Chem., 2010, 118, 489496.

145 H. Chang, Y. Ho, M. Sheu, Y. Lin, M. Tseng, S. Wu, G. Huang and Y. Chang, Bot. Stud., 2007, 48, 407-417.

146 P. Evelson, M. Travacio, M. Repetto, J. Escobar, S. Llesuy and E. A. Lissi, Arch. Biochem. Biophys., 2001, 388, 261-266.

147 H. Leontowicz, S. Gorinstein, A. Lojek, M. Leontowicz, M. Ciz, R. Soliva-Fortuny, Y. Park and S. Jung, J. Nutr. Biochem., 2002, 13, 603-610.

148 M. G. Repetto and S. F. Llesuy, Braz. J. Med. Biol. Res., 2002, 35, 523-534.

149 P. Miciński, K. Pawlicki, E. Wielgus, M. Bochenek, P. Gogol and B. Ficek, Reprod. Biol., 2011, 11, 135-144.

150 R. He, Y. Li, X. Li, R. Yi, X. Wang, B. Tsoi, K. K. H. Lee, K. Abe, X. Yang and H. Kurihara, PLoS One, 2013, 8, e57732. 
151 F. S. Hosseinian, A. D. Muir, N. D. Westcott and E. S. Krol, Org. Biomol. Chem., 2007, 5, 644-654.

152 S. Kohtani, K. Yoshida, T. Maekawa, A. Iwase, A. Kudo, H. Miyabe and R. Nakagaki, Phys. Chem. Chem. Phys., 2008, 10, 2986-2992.

153 H. Esterbauer, J. H. Gebicki and G. Jürgens, Free Radical Biol. Med., 1992, 13, 341-390.

154 E. Niki, Y. Yoshida, Y. Saito and N. Noguchi, Biochem. Biophys. Res. Commun., 2005, 338, 668-676.

155 T. A. Dix and J. Aikens, Chem. Res. Toxicol., 1993, 6, 2-18.

156 V. Mišík, K. Ondriaš and P. Balgavý, Gen. Physiol. Biophys., 1992, 11, 317-325.

157 K. Marshall, R. J. Reiter, B. Poeggeler, O. I. Aruoma and B. Halliwell, Free Radical Biol. Med., 1996, 21, 307-315.

158 O. I. Aruoma, in Free radicals in tropical diseases, Harwood Academic Publishers, 1993.
159 O. I. Aruoma, Free Radical Biol. Med., 1996, 20, 675-705.

160 C. L. Alarcón and A. Denicola, Anal. Chim. Acta, 2013, 763, 1-10.

161 K. L. Wolfe and R. H. Liu, J. Agric. Food Chem., 2007, 55, 8896-8907.

162 D. Honzel, S. G. Carter, K. A. Redman, A. G. Schauss, J. R. Endres and G. S. Jensen, J. Agric. Food Chem., 2008, 56, 8319-8325.

163 J. A. Royall and H. Ischiropoulos, Arch. Biochem. Biophys., 1993, 302, 348-355.

164 M. Antolovich, P. D. Prenzler, E. Patsalides, S. McDonald and K. Robards, Analyst, 2002, 127, 183-198.

165 R. Apak, S. Gorinstein, V. Böhm, K. M. Schaich, M. Özyürek and K. Güçlü, Pure Appl. Chem., 2013, 85, 957-998. 